\title{
Histological Study of the Effect of Tributyltin on the Adrenal Cortical Cells of Adult Male Albino Rats
}

\section{Original Article}

\author{
Amany Abd El-Moneim Solaiman and Silvia Kamil Seddik Sawires
}

Department of Histology and Cell Biology, Faculty of Medicine, Alexandria University, Egypt

\begin{abstract}
Background: Tributyltin is widely used as antifouling paint for marine vessels. It is slowly released from the paint to the water and becomes incorporated into soil, animals and plants. TBT has been identified as an endocrine disruptor and induces oxidative damage.

Objectives: This study aimed to investigate the probable toxic effect of tributyltin on adrenal cortical cells of adult male albino rats for two different durations.

Materials and Methods: Twenty four adult male albino rats were divided into 3 equal groups: Group I: was the control group; Group II: each rat received tributyltin orally at a dose of $1 \mathrm{mg}$ daily for one week. Group III: received the same daily dose for successive two weeks. At the end of the experiment, the animals were sacrificed and blood samples were subjected to hormonal assay for aldosterone, corticosterone and ACTH levels. Serum tin levels were assessed. The adrenal tissue was processed for light and electron microscopic examination. In addition, immunoreaction for CD 44 positive cells was performed.

Results: A significant decrease in aldosterone and corticosterone, an increase in ACTH levels and an increase in the mean count of CD44 positive cells in group III have been revealed when compared with the other groups. Histological changes in group II were shown in zona glomerulosa and fasciculata in the form of loss of architecture, cytoplasmic vacuolation and disrupted mitochondrial cristae. Meanwhile, Group III showed few lipid droplets and deeply stained nuclei in both zones. Conclusion: Tributyltin has deleterious effects on cells of zona glomerulosa and zona fasciculata of the adrenal cortex of adult male albino rats which were time-dependent.
\end{abstract}

Received: 14 June 2019, Accepted: 06 August 2019

Key Words: Adrenal cortex; histology; triburyltin.

Corresponding Author: Amany Abd El-Moneim Solaiman, MD, Department of Histology and Cell Biology, Faculty of Medicine, Alexandria University, Egypt, Tel.: +20 1096366227, E-mail: amanysolaiman@gmail.com

ISSN: $1110-0559$, Vol. 43, No. 1

\section{INTRODUCTION}

The potential adverse effects of environmental chemicals, such as endocrine disruptors grape more attention in national and international health organizations, as well as being a political issue in various countries ${ }^{[1]}$. An endocrine disruptor is defined, according to the World Health Organization (WHO) as "an exogenous substance or mixture that modulates function(s) of the endocrine system and consequently causes adverse effects in intact organisms, or its progeny, or (sub) populations" ${ }^{[2]}$.

Organotin compounds (OT), such as tributyltin (TBT), have been widely used in a wide variety of consumer products as they were wrongly deemed safe environmentally. They have been utilized as biocides, in food storage (canned foods) and to make stainless steel ${ }^{[3]}$. Moreover, TBT has been used as antifouling paints for marine vessels and fishing nets. It is a lipophilic structure that is slowly released from the paint to the water and tends to accumulate in seafood and shellfish. Degradation of TBT involves breakage of the carbon-tin bond with the formation of toxic derivatives and tin $\operatorname{ion}^{[4]}$. They have been shown to be incorporated into soil, animals, fish and plants of aquatic ecosystem ${ }^{[5]}$.

TBT exposure can lead to alternation in the immune ${ }^{[6]}$ and reproductive systems ${ }^{[7]}$. Recent studies have reported that TBT toxicity is considered as environmental factor for obesity by disturbing the levels of key hormones linked to energy homeostasis ${ }^{[8]}$.

TBT has been identified as an endocrine disruptor and capable of altering the endocrine physiology at numerous levels: changing pattern of hormone regulation, production, mechanisms of action or hormone elimination and mimicking or blocking hormonal action ${ }^{[9]}$.

The adrenal gland contains two regions; cortex and medulla. The adrenal cortex is divided into 3 distinct zones, each of which secretes important hormone ${ }^{[10]}$. Aldosterone is a mineralocorticoid secreted from zona glomerulosa and acts as a modulator of electrolyte balance in the body. The zona fasciculata secretes glucocorticoid which modulate metabolic and immune functions. Zona reticularis participates in androgen production except in 
rodents due to lack of zone specific enzyme required for the androgen production ${ }^{[11]}$

Some researchers suggested that organotin can induce oxidative damage both in vivo and in vitro. The overproduction of reactive oxygen species (ROS) causes cellular oxidative injury such as lipid peroxidation, protein oxidation, and DNA damage ${ }^{[12]}$.

CD44 comprises a family of cell adhesion characteristic for mesenchymal stem cells. Investigators discovered stem/ progenitor cells in the adrenal gland that can differentiate to repopulate zones ${ }^{[1]}$.

Taken the above-mentioned considerations, the present study was conducted specifically, to investigate the probable toxic effect of TBT on adrenal cortical cells of adult male albino rats in two different durations.

\section{MATERIALS}

\section{Chemicals}

Tributyltin chloride (in the form of liquid with purity (96\%) and corn oil were purchased from Sigma-Aldrich Chemical Company, St. Louis, MO, USA.

\section{Animals and experimental design}

The present study was carried out on 24 adult male albino rats, aged 3-4 months and their body weight ranged between 240 and $250 \mathrm{~g}$. The animals were kept under standard laboratory conditions of temperature, humidity and 12 hours light/dark cycle with free access to the ordinary rat food and water ad -ibitum. Guidelines for the care and use of animals approved by the Animal House Center, Faculty of Medicine, University of Alexandria, were followed. All procedures were approved by the Ethics Committee of the Faculty of Medicine, Alexandria University.

\section{The animals were randomly divided into 3groups}

\section{Group I (Control group)}

12 rats were divided into two equal subgroups, each of 6 animals:

Subgroup Ia: kept as a negative control, they were left without any treatment, half of these animals were sacrificed with group II and the remaining animals were sacrificed with group III.

Subgroup Ib: kept as a positive control each animal received $0.4 \mathrm{ml}$ of corn oil (the vehicle of TBT) once daily by gastric tube. Half of the animals were sacrificed with group II (after one week) and the remaining animals were sacrificed with group III (after two weeks).

\section{Group II}

This group included six rats each rat received TBT at a dose of $1 \mathrm{mg}$ dissolved in $0.4 \mathrm{ml}$ corn oil once daily by gastric tube for one week ${ }^{[13]}$.
Group III: included six rats that received the same dose of TBT as group II for two weeks.

Twenty-four hours after the last dose of TBT, animals were sacrificed by intraperitoneal injection of pentobarbital at a dose of $50 \mathrm{mg} / \mathrm{kg}$ body weight ${ }^{[14]}$.

\section{METHODS}

\section{I- Hormonal assay}

Blood samples from the tail vein of all animals included in this study were collected at 8:00 am in the morning ${ }^{[15]}$. Samples were kept in ethylenediamine-tetraacetic acid (EDTA) tubes, centrifuged at $2000 \times \mathrm{g}$ for $10 \mathrm{~min}$. and sera were stored at $-20^{\circ} \mathrm{C}$ until analysis.

Serum concentrations of corticosterone, aldosterone and adrenocorticotropic hormone (ACTH) were analyzed at the Biochemistry Department, Faculty of Medicine, University of Alexandria.

Mouse/Rat solid phase enzyme-linked immunosorbent assay (ELISA) Kits (Sigma-Aldrich Chemical Company, St. Louis, Missouri, USA) were used for measurement of serum corticosterone and ACTH. Serum aldosterone was measured by mouse aldosterone ELISA Kits(abcamCambridge, UK).

\section{II- Tin assessment}

To assess serum tin levels, another $2 \mathrm{ml}$ of blood samples were collected at the time of sacrifice, tin levels were measured using an inductively coupled plasma atomic emission spectrometry (ICP-OES Agilent 5100VDV Santa Clara, USA $)^{[16]}$. The analysis was performed at the Institute of Graduate Studies and Research labs, Alexandria University.

\section{III-Histological study}

24 Hours after the end of the experimental periods, the right adrenal gland of each animal was divided in the sagittal plane into two halves.

The first halves of the right adrenal glands were fixed in $10 \%$ formol saline and processed for light microscopic examination. Sections of $5-6 \mu \mathrm{m}$ thick were cut and subjected to:

1. Hematoxylin and eosin (H \& E) staining ${ }^{[17]}$.

2. Immunohistochemical detection of CD44 ${ }^{[18]}$.

For detection of CD44 positive cells, paraffin sections were stained with anti- CD44 by routine immunehistochemical avidin-biotin method at the Clinical Pathology Department, Faculty of Medicine, University of Alexandria.

Immunohistochemical staining was performed on paraffin blocks that were sectioned at $4 \mu \mathrm{m}$ thickness and placed on poly-l-lysine-coated glass slides. The primary antibody was Rabbit monoclonal antibody against CD44 
(anti-CD44 antibody with a dilution of 1: 200, overnight at $4{ }^{\circ} \mathrm{C}$ ) (Abcam, Cambridge, UK). Negative control slide was included by omitting the primary antibody. All slides were deparaffinized and then rehydrated in decreasing concentrations of ethanol. Inhibition of endogenous peroxidase activity, using 3\% hydrogen peroxidase for 15 min. Antigen retrieval was carried out using microwave heating (20 min; $10 \mathrm{mmol} /$ citrate buffer, $\mathrm{pH} 6.0)$. The primary antibody was applied to the slides and incubated overnight at room temperature and then incubated with secondary antibody for 1 hour at room temperature. A $0.1 \%$ solution of diaminobenzidine was used for $5 \mathrm{~min}$ as a chromogen. Sections of tonsil with known CD44 expression were used as positive control. CD44 +ve cells showed a brownish reaction.

The second half was immediately cut into small pieces $\left(1 \times 1 \mathrm{~mm}^{3}\right)$ and fixed in $3 \%$ phosphate-buffered gluteraldehyde solution and processed for transmission electron microscopic study ${ }^{[19]}$. Semi-thin sections were cut using ultramicrotome (Leica, Sweden) and stained with toluidine blue, and then used for identification of adrenocortical zones. Ultra-thin sections were stained with lead citrate, and examined using a Jeol 1400 plus (Tokyo, Japan), at theFaculty of Science, University of Alexandria.

\section{IV-Morphometric study and statistical analysis}

For each group, six random fields/section from each animal were chosen and the number of CD 44+ve cells was counted at $x 400$ and photographed.

Statistical analysis was performed using the statistical software package for the social sciences (SPSS, version 20; IBM SPSS, Chicago, Illinois, USA) software package. The obtained data were expressed as mean \pm standard deviation and analyzed using analysis of variance (ANOVA).The statistical significance level was defined as $p \leq 0.05$.

\section{RESULTS}

\section{I- Hormonal assay results}

The study revealed no significant difference in the studied hormone levels between the control subgroups. Animals of group II showed non-significant changes in mean serum levels of corticosterone, aldosterone and ACTH as compared to the control group. On the other hand, animals of group III showed a significant decrease in mean serum levels of aldosterone and corticosterone with a compensatory significant increase in ACTH level as compared to control group and group II ( $p \leq 0.05)$ (Table I).

\section{II- Tin assessment results}

TBT exposure led to increase in serum tin levels in groups II and III rats $(p \leq 0.05)$ when compared with control rats. Additionally, the serum tin levels in group III rats showed a significant increase $(p \leq 0.05)$ as compared to group II (Table II).

\section{III- Histological results}

\section{1- Light microscopic results}

a. $H \& E$ stain

\section{Group I (control group)}

Light microscopic examination of the control group revealed the normal architecture of adrenal gland which was covered externally by a capsule of dense connective tissue. The zona glomerulosa ( $\mathrm{ZG}$ ) occupied a narrow zone underneath the capsule (Figures 1 and 2), followed by a middle wide zona fasciculata (ZF) (Figures 1 and 3) and the innermost zona reticularis (ZR) which merged with the medulla (Figure 4).

The ZG was formed of clusters of rounded or arched groups of columnar cells with pale vacuolated cytoplasm (Figures 1 and 2) and oval nuclei (Figure 2).

The ZF was the widest cortical zone constituting the majority of the cortical thickness. It was formed of regularly arranged parallel longitudinal cords of polyhedral cells being one or two cells thick. The cytoplasm was eosinophilic and vacuolated. The nuclei were central and vesicular. The cords of cells were separated by intervening narrow sinusoidal capillaries (Figure 3 ). The ZR constituted the innermost zone of the adrenal cortex. It was clearly limited in its inner border from the medullary cells. However, its outer border was continuous with the fasciculata cell cords. The ZR cells are small, closely packed and deeply eosinophilic polyhedral cells arranged in short irregular network of intermingled cords of cells (Figure 4).

\section{Group II}

Sections of the adrenal cortex of group II revealed evident histological changes. ZG showed loss of the arcade pattern of the cells. The cells were arranged in irregular arcades under the connective tissue capsule. Many of the glomerulosa cells appeared ballooned with encroachment on the intervening sinusoidal capillaries. Their cytoplasm appeared vacuolated with deeply stained nuclei (Figure 5).

The ZF showed loss of the regular arrangement of its cells with obviously ballooned vacuolated cells and deeply stained nuclei. Some cells exhibited deep eosinophilic cytoplasm and deeply stained nuclei (Figure 6). The ZR cells were arranged in cords interspersed by sinusoidal capillaries (Figure 7).

\section{Group III}

After two weeks, the adrenal cortex revealed progressive histological alterations in ZG and ZF with evident cellular disorganization. In fact, many cells of the ZG lost their disposal in arches and appeared with hyperoesinophilic cytoplasm and deeply stained nuclei. (Figure 8) 
As for the cells of ZF they were no longer arranged in parallel cords but showed random disposal. Most of the cells revealed swollen vacuolated cytoplasm (Figures 8 and 9), others showed hypereosinophilic cytoplasm with deeply stained nuclei (Figure 9) ZR exhibited disorganized ballooned vacuolated cells (Figure 10).

\section{b-Immunohisotchemical and morphometric results}

Immunohistochemical staining for CD44 in the control group demonstrated negative reaction (Figure 11a), while group II revealed only some CD44 +ve cells (Figure 11b). In contrast, group III showed multiple CD44 +ve cells among the cortical cells (Figure 11c). the tonsil was used as positive control.

The mean count of CD44 +ve cells, a significant increase was detected in group III compared to group I and group II (Table III).

\section{2- Ultrastructural results}

\section{Group I ( control group)}

The cells of ZG were arranged in arches just beneath the connective tissue capsule. They were recognized by their euchromatic nuclei. Their cytoplasm showed many lipid droplets. The mitochondria exhibited shelf like cristae (Figures 12a, b and c).

In the ZF, the cells revealed rounded euchromatic nuclei and many lipid droplets. Numerous mitochondria with vesicular cristae, profiles of smooth endoplasmic reticulum and a small Golgi complex were further encountered (Figures 13a and b).

In the control animals, the cells of the ZR revealed abundant mitochondria. They were mainly rounded or ovoid in shape, variable in sizes with vesicular or tubulovesicular cristae and occupied most of the cytoplasm. Occasionally lysosomes and lipofuscin pigments were also seen. The cells further revealed well developed intercellular junctions (Figures 14a and b).

\section{Group II}

Most of the ZG cells exhibited euchromatic nuclei, while few were heterochromatic (Figures 15a and b).
The cytoplasm revealed accumulation of lipid droplets (Figures 15a and b), mitochondria with disrupted cristae and few lysosomes (Figure $15 \mathrm{c}$ ).

Cells of ZF revealed cytoplasmic lipid droplets of variable sizes. (Figure 16a) Some mitochondria exhibited ill- defined cristae (Figure 16b). In addition, the cytoplasm showed multiple myelin figures and lysosomes (Figure 16b).

As for ZR, some cells revealed irregular nuclei with dispersed chromatin (Figure 17a). Many mitochondria showed tubulo-vesicular cristae(Figure 17b).

\section{Group III}

Some ZG cells showed small heterochromatic nuclei (Figure 18a). The cells showed relatively few lipid droplets with electron-dense cytoplasm (Figures 18b, $19 \mathrm{a}$ and b) and mitochondria with disrupted cristae (Figure 19c). The cells further exhibited lysosomes, lipofuscin pigments (Figure 19a) and myelin figures (Figures $19 \mathrm{a}$ and b). Moreover, cells displayed polygonal morphology with cellular extensions and euchromatic nuclei were frequently observed especially near the sinusoidal capillaries (Figure 19b).

Ultrastructurally, the fasciculata cells showed some irregular nuclei and others with dense nuclei (Figure 20a). The cytoplasm of some cells showed many lipid droplets (Figures 20a and b), while others had sparse lipid droplets (Figure 20a). The mitochondria appeared with ill- defined cristae (Figure 20c). This zone showed many cells which displayed polygonal morphology and euchromatic nuclei. Particularly, their cytoplasm displayed few profiles of rough endoplasmic reticulum (Figure 20b) and a centriole (Figure 20a). The cell membrane had multiple cellular extensions which extended between neighboring cells (Figure 20b).

ZR cells of this group revealed cords of cells separated by large sinusoidal capillaries. Some cells appeared with irregular nuclei with dispersed chromatin. The cytoplasm revealed lysosomes and scanty lipid droplets (Figure 21a). Many mitochondria showed intact tubulovesicular cristae(Figure 21b). 
Table I: Median and mean $\pm \mathrm{SD}$ of corticosterone, aldosterone and $\mathrm{ACTH}$ in the different studied groups

\begin{tabular}{|c|c|c|c|c|c|}
\hline & Ia $(n=6)$ & $\mathrm{Ib}(\mathrm{n}=6)$ & II $(n=6)$ & III $(n=6)$ & $\mathrm{F}(p)$ \\
\hline \multicolumn{6}{|l|}{ Corticosterone $(\mathrm{ng} / \mathrm{ml})$} \\
\hline Median (Min. - Max.) & $84.0(80.2-88.7)$ & $84.2(80.2-88.6)$ & $82.4(80.5-83.4)$ & $56.7(45.0-57.8)$ & \multirow{2}{*}{$\begin{array}{l}106.424^{*} \\
\left(<0.001^{*}\right)\end{array}$} \\
\hline Mean \pm SD & $83.7 \pm 3.2$ & $84.0 \pm 3.4$ & $82.3 \pm 1.0$ & $54.7^{\mathrm{abc}} \pm 4.9$ & \\
\hline \multicolumn{6}{|l|}{ Aldosterone (pg/ml) } \\
\hline Median (Min. - Max.) & $128.2(123.6-130.1)$ & $126.3(122.7-130.0)$ & $126.1(123.2-129.0)$ & $63.4(60.9-65.8)$ & \multirow{2}{*}{$\begin{array}{l}941.749^{*} \\
\left(<0.001^{*}\right)\end{array}$} \\
\hline Mean $\pm \mathrm{SD}$ & $127.56 \pm 2.73$ & $126.4 \pm 3.12$ & $125.9 \pm 2.05$ & $63.51^{\mathrm{abc}} \pm 2.02$ & \\
\hline \multicolumn{6}{|l|}{$\mathrm{ACTH}(\mathrm{pg} / \mathrm{ml})$} \\
\hline Median (Min. - Max.) & $8.1(7.6-8.5)$ & $8.1(7.6-8.5)$ & $8.1(7.8-8.5)$ & $182.3(172.6-190.3)$ & \multirow{2}{*}{$\begin{array}{l}3979.943^{*} \\
\left(<0.001^{*}\right)\end{array}$} \\
\hline Mean \pm SD & $8.07 \pm 0.43$ & $8.06 \pm 0.42$ & $8.16 \pm 0.31$ & $182.3^{\mathrm{abc}} \pm 6.73$ & \\
\hline
\end{tabular}

F,p: $\mathrm{F}$ and $p$ values for ANOVA test, Significance between groups was done using Post Hoc Test (Tukey)

*: Statistically significant at $p \leq 0.05$

a: significant with group Ia, b: significant with group Ib, c: significant with group II

Table II: Median and mean \pm SD of serum concentration of tin in the different studied groups

\begin{tabular}{|c|c|c|c|c|}
\hline Serum concentration of tin $(\mathrm{mg} / \mathrm{ml})$ & Ia $(n=6)$ & $\mathrm{Ib}(\mathrm{n}=6)$ & II $(n=6)$ & III $(n=6)$ \\
\hline Median (Min. - Max.) & $0.018(0.016-0.018)$ & $0.018(0.016-0.018)$ & $3.555(3.49-3.65)$ & $6.285(6.22-6.32)$ \\
\hline Mean \pm SD & $0.018 \pm 0.001$ & $0.017 \pm 0.001$ & $3.560^{\mathrm{ab}} \pm 0.059$ & $6.278^{\mathrm{abc}} \pm 0.039$ \\
\hline $\mathrm{F}$ & \multicolumn{4}{|c|}{$44911.517^{*}$} \\
\hline$P$ & \multicolumn{4}{|c|}{$<0.001^{*}$} \\
\hline
\end{tabular}

p: F and $p$ values for ANOVA test, Significance between groups was done using Post Hoc Test (Tukey)

*: Statistically significant at $p \leq 0.05$

a: significant with group Ia, b: significant with group Ib, c: significant with group II

Table III: Median and mean \pm SD according to count of CD44+ve cells in the different studied groups

\begin{tabular}{|c|c|c|c|c|}
\hline CD44 & Ia $(n=6)$ & $\mathrm{Ib}(\mathrm{n}=6)$ & II $(n=6)$ & III $(n=6)$ \\
\hline Median (Min. - Max.) & $0.0(0.0-0.0)$ & $0.0(0.0-0.0)$ & $2.0(1.0-3.0)$ & $4.0(3.0-6.0)$ \\
\hline Mean \pm SD & $0.0 \pm 0.0$ & $0.0 \pm 0.0$ & $2.0^{\mathrm{ab}} \pm 0.89$ & $4.17^{\mathrm{abc}} \pm 1.17$ \\
\hline $\mathrm{F}$ & \multicolumn{4}{|c|}{$43.769^{*}$} \\
\hline$P$ & \multicolumn{4}{|c|}{$<0.001^{*}$} \\
\hline
\end{tabular}

p: F and $p$ values for ANOVA test, Significance between groups was done using Post Hoc Test (Tukey)

*: Statistically significant at $p \leq 0.05$

a: significant with group Ia, b: significant with group Ib, c: significant with group II

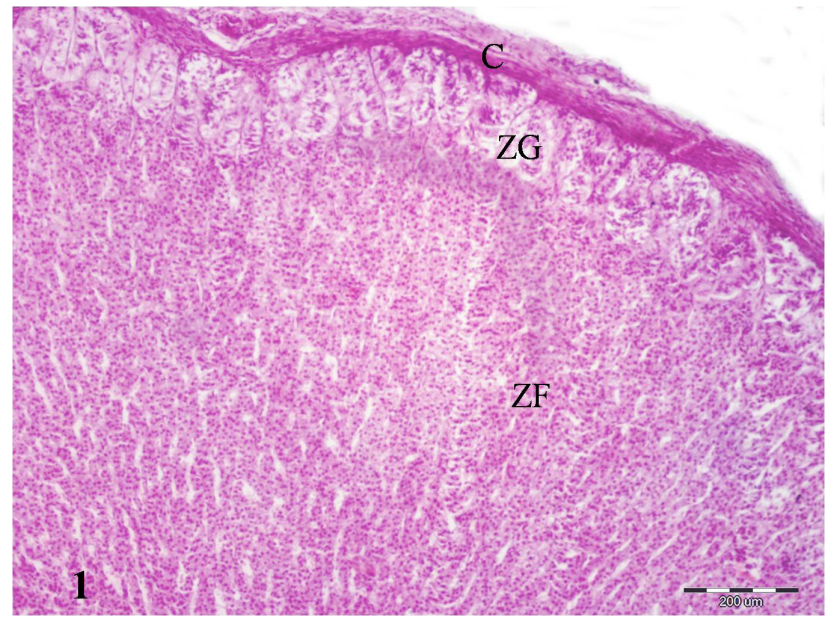

Fig.1: Light photomicrograph of group I (control group) showing part of the adrenal cortex covered by a connective tissue capsule (C). Beneath the capsule, the cells of the zona glomerulosa (ZG) are seen. The next wider zone is the zona fasciculata $(\mathrm{ZF})$ with a regular arrangement of its cells. (H\&Ex 400).

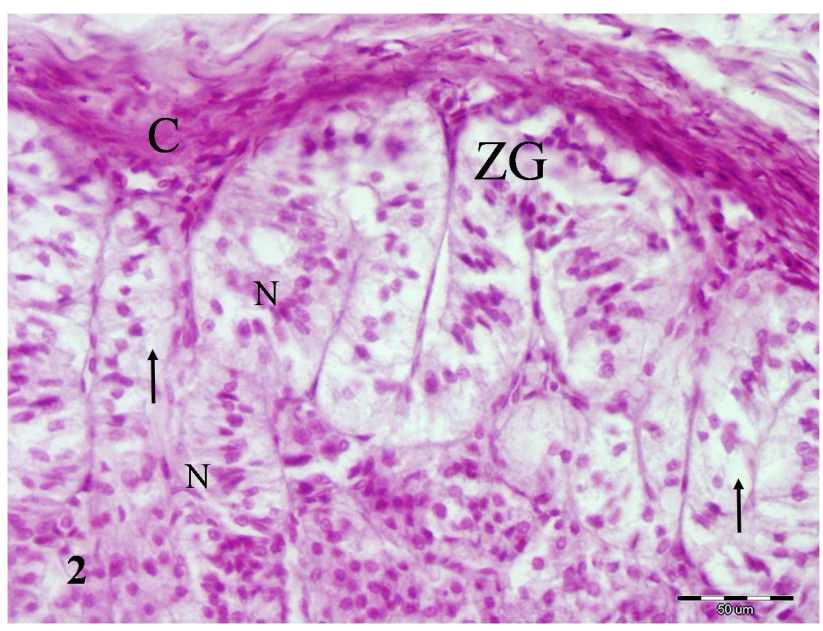

Fig. 2: A section in the adrenal cortex of the control group showing the connective tissue capsule (C) and part of the underlying ZG. It is formed of columnar cells arranged in regular arcades with and pale vacuolated cytoplasm (arrow) and oval nuclei $(\mathrm{N})$. (H\&Ex 400). 


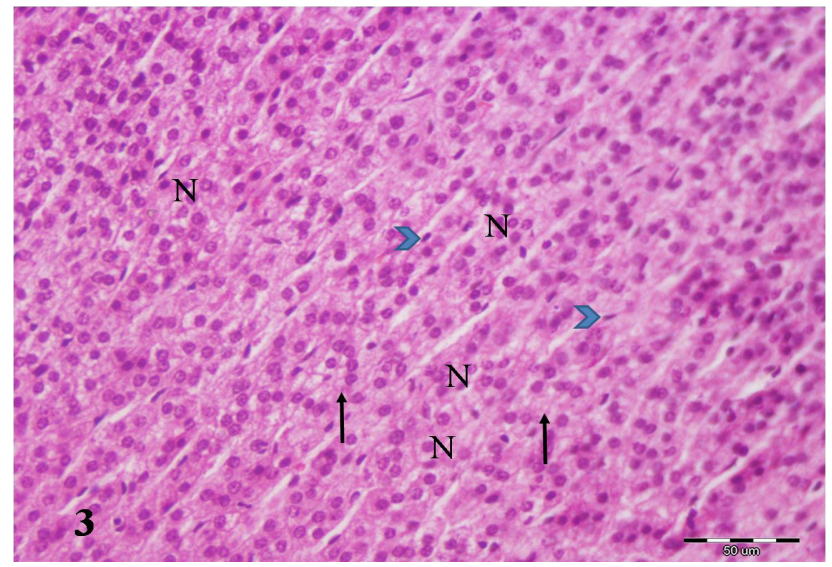

Fig. 3: Light photomicrograph of control group showing cells of the ZF arranged in straight cords one or two cells thick. The cells are polygonal with central vesicular nuclei $(\mathrm{N})$. The cytoplasm is eosinophilic and vacuolated (arrow). Straight narrow sinusoidal capillaries between the cell cords lined by flat endothelial cells (arrowhead) are also seen. (H\&Ex 400).

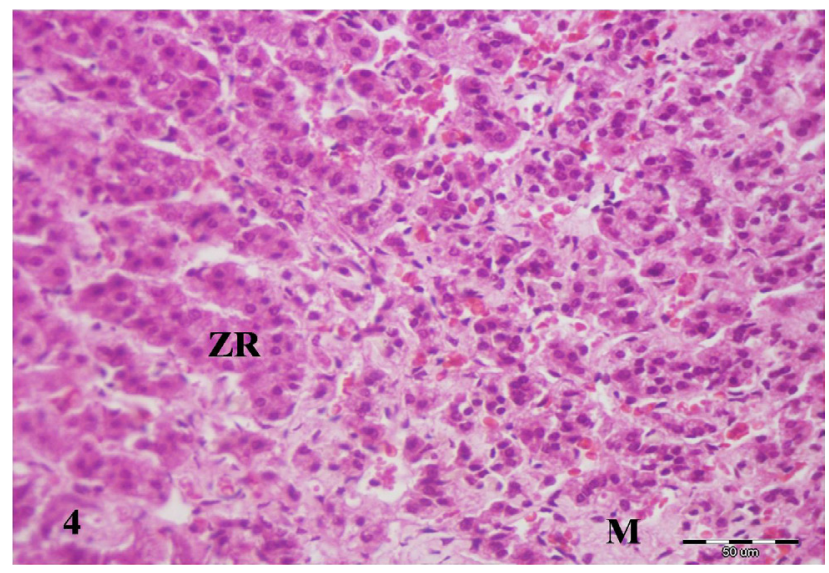

Fig. 4: Light photomicrograph of a part of adrenal cortex of the control group showing zona reticularis(ZR) with anastomosing cords of cells. M; medulla. (H\&Ex 400).

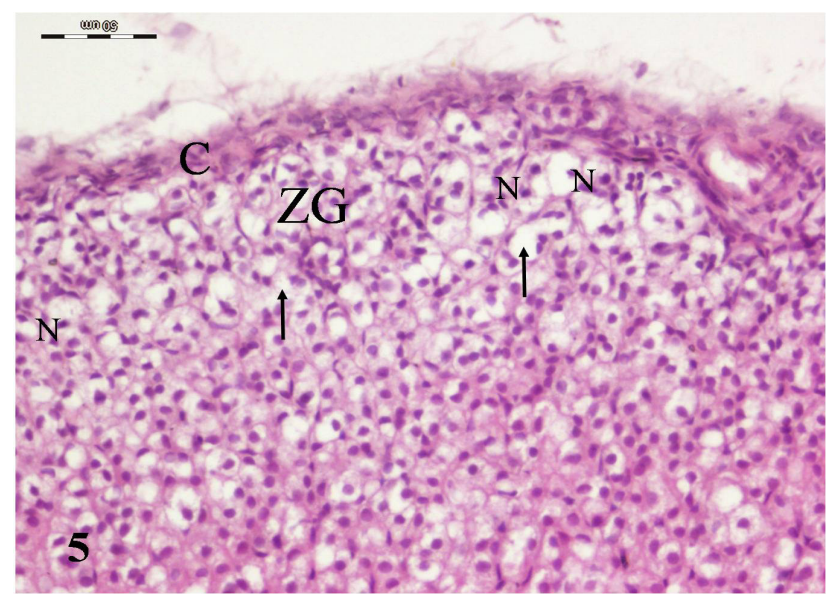

Fig. 5: Light photomicrograph of the adrenal cortex of group II revealing ZG beneath the capsule (C) with loss of normal architecture. Most of the cells exhibit swollen vacuolated cytoplasm (arrow) and multiple deeply stained nuclei $(\mathrm{N})$. (H\&Ex 400)

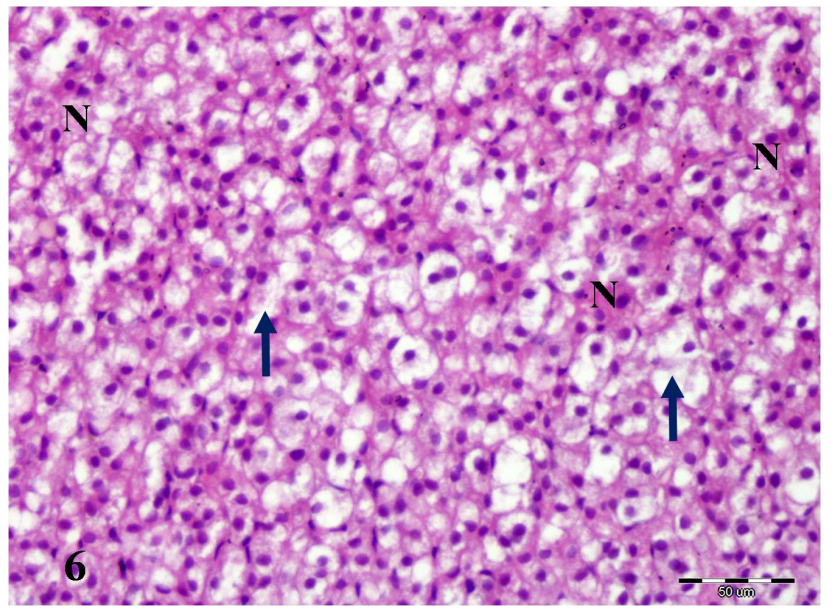

Fig. 6: Light photomicrograph of ZF of group II. Many cells are swollen with extensive cytoplasmic vacuolation (arrow). Some cells show deeply eosinophilic cytoplasm and deeply stained nuclei $(\mathrm{N}) .(\mathrm{H} \& \mathrm{Ex} 400)$

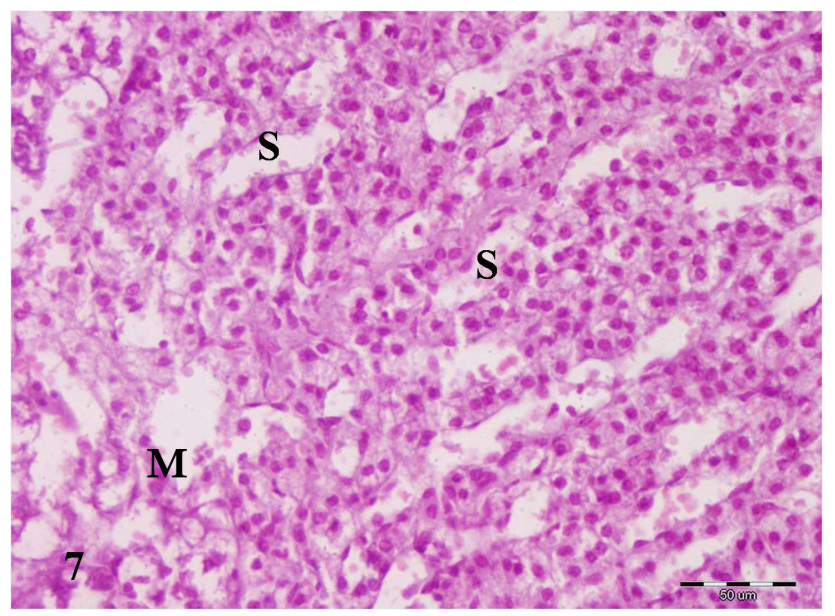

Fig. 7: Light photomicrograph of ZR of group II. The cells are arranged in anastomosing cords separated by wide sinusoidal capillary (S).M; medulla (H\&Ex 400)

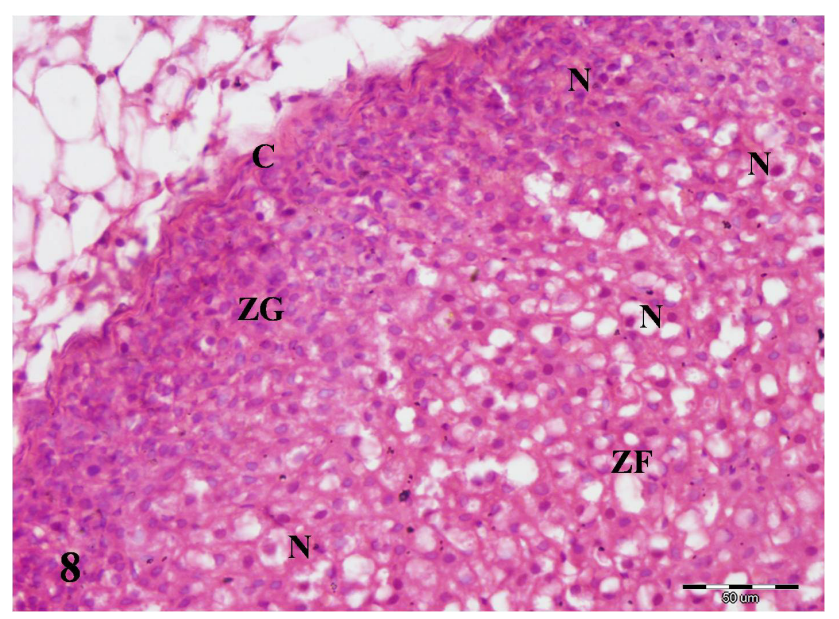

Fig. 8: Light photomicrograph of part of the adrenal cortex of group III showing distorted architecture of ZG. The cells show hypereosinophilic cytoplasm and deeply stained nuclei (N). Cells of the zona fasciculata (ZF) are ballooned and vacuolated. C; connective tissue capsule. (H\&Ex 400) 


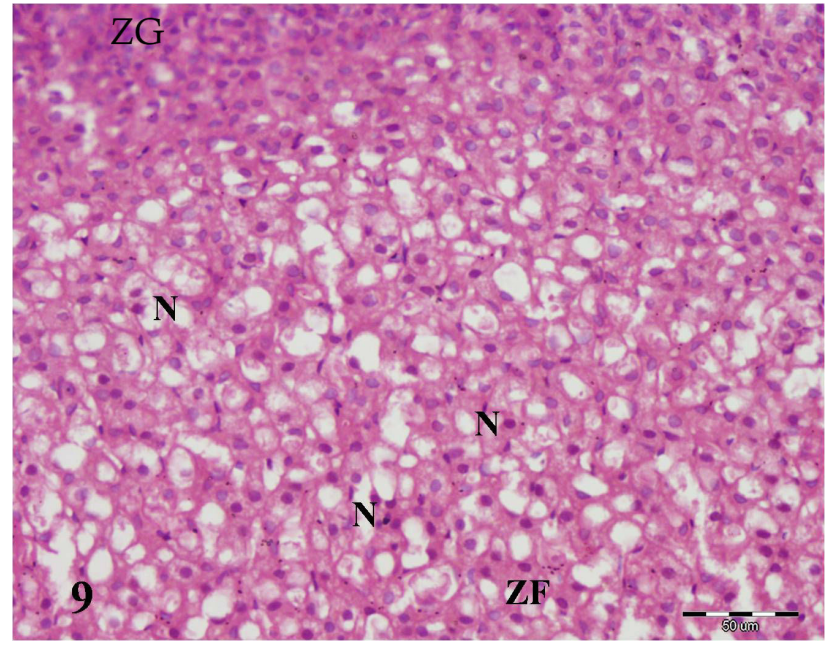

Fig. 9: A section in ZF of adrenal cortex of group III showing disorganized arrangement of its cells. The cells appear ballooned and vacuolated. Others show hyperoesinophilic cytoplasm and deeply stained nuclei (N). ZG; zona glomerulosa (H\&Ex 400)

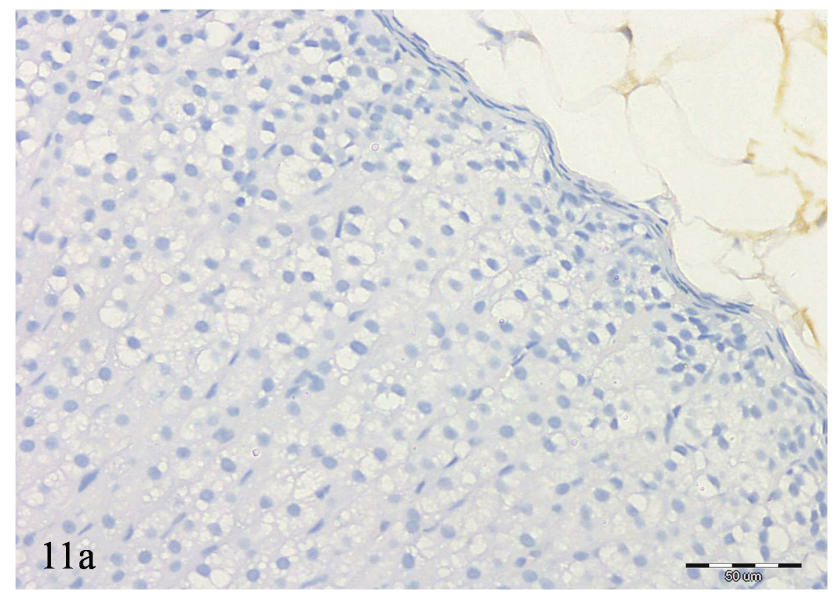

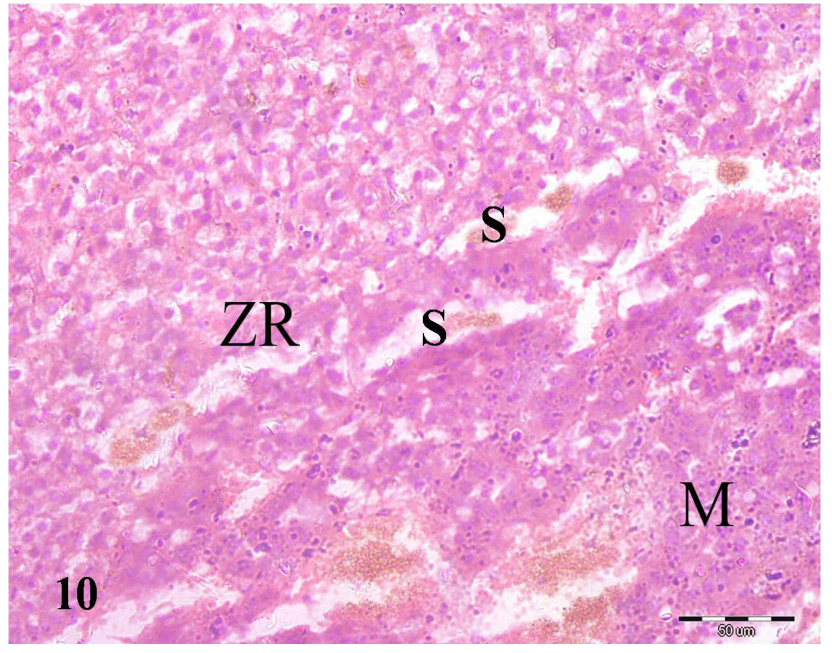

Fig. 10: A section in the ZR of the adrenal cortex of group III showing disorganized ballooned vacuolated cells separated by sinusoidal capillaries (S). M; medulla. (H\&E x 400)

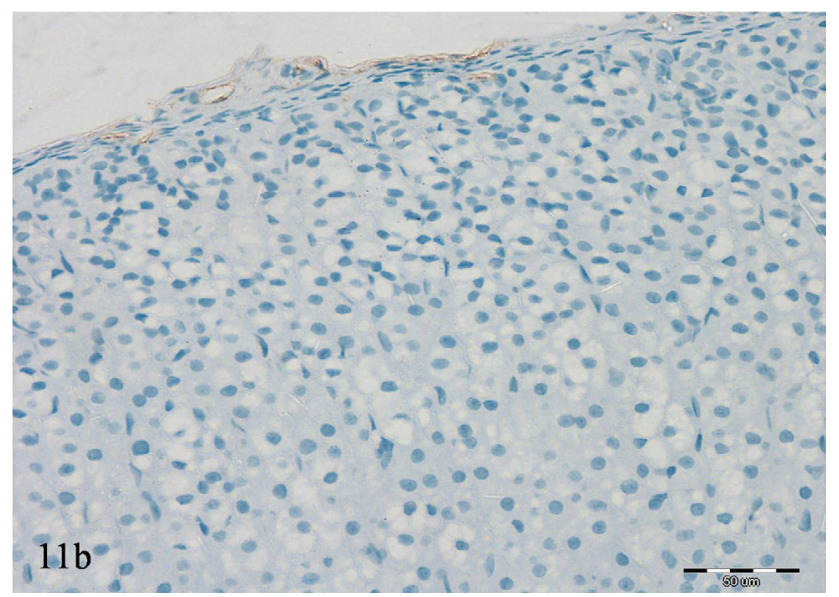

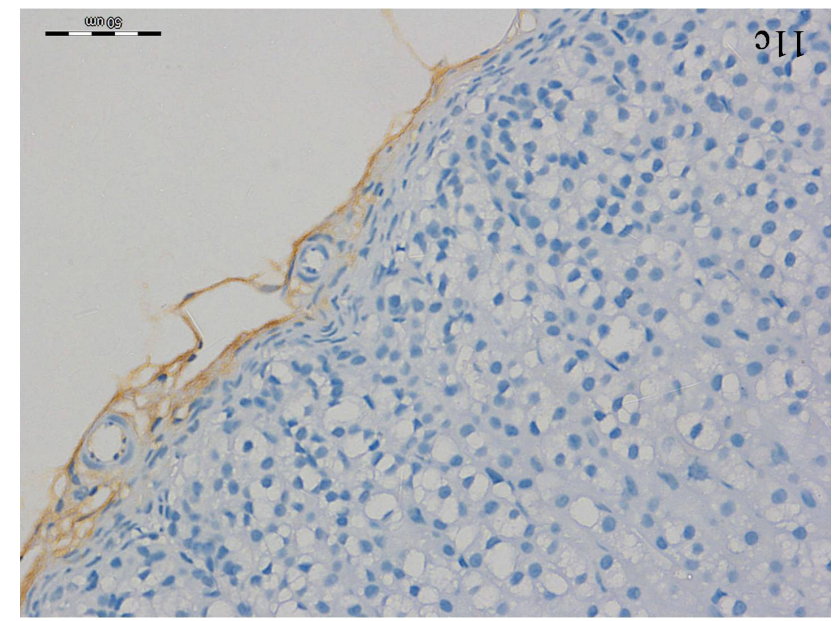

Fig. 11(a-c): Photomicrographs of sections in the adrenal gland: a) group I demonstrating negative immune expression. b: group II demonstrating few CD 44+ve cells at the capsule. c)group III showing multiple CD 44+ve cells. (CD44 immunostaining a-c x 400) 

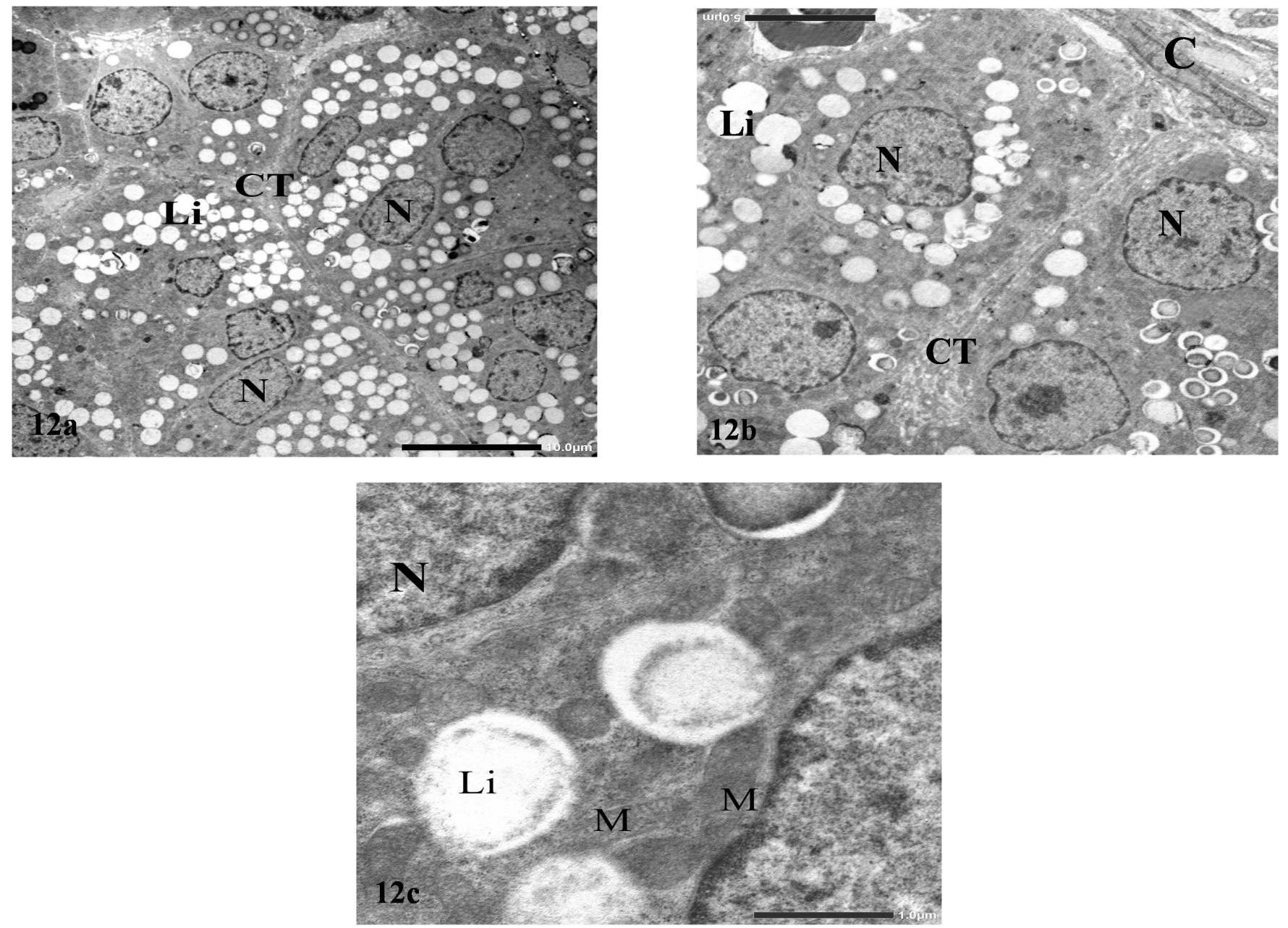

Fig. 12a-c: Electron micrographs of a part of the adrenal cortex of group I showing a,b) a group of ZG cells separated by thin connective tissue septa (CT). The connective tissue capsule (C) is seen overlying group of glomerulosa cells in b. The cells have euchromatic nuclei (N). The cytoplasm contains some lipid droplets (Li). c) A high magnification showing multiple mitochondria (M) with shelf like cristae in the cytoplasm. Li; lipid droplet, N; nucleus. ax 800,bx1500,cx8000
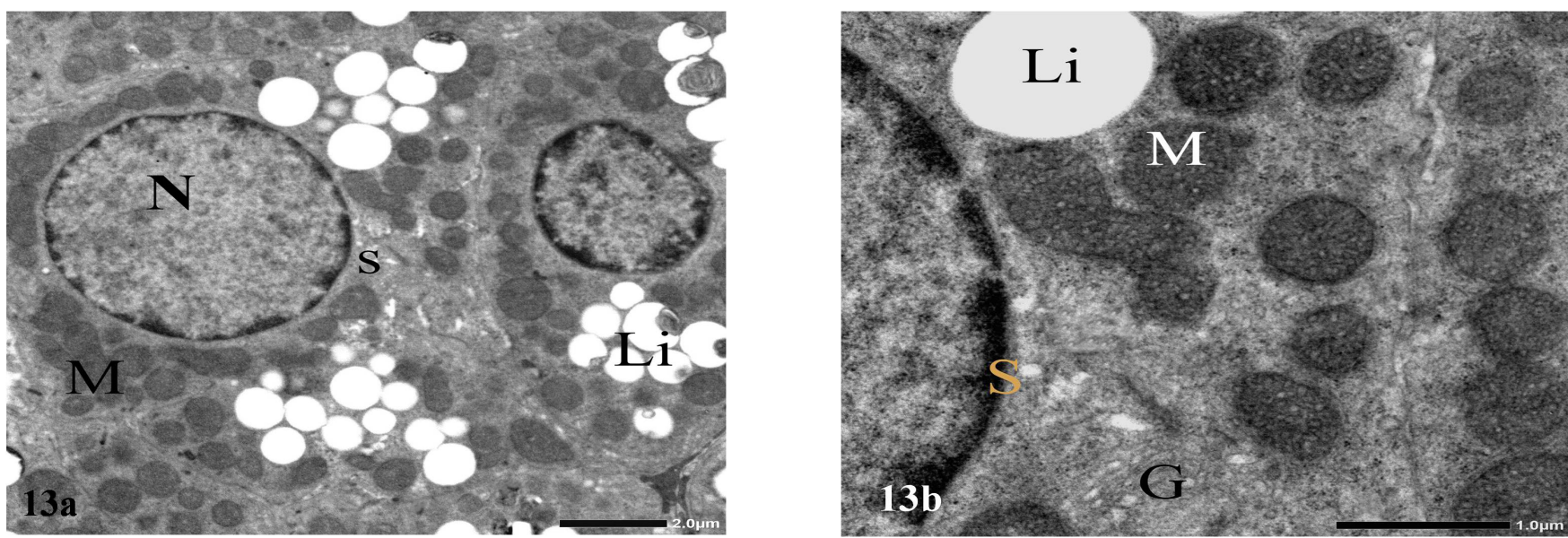

Fig. 13a,b: Electron micrographs of the zona fasciculata cells of group I showing; a) Adjacent cells with rounded euchromatic nuclei (N) and intracellular lipid droplets ( $\mathrm{Li}$ ) of varying sizes. The cytoplasm shows profiles of smooth endoplasmic reticulum (S). M; mitochondria. b) Parts of two adjacent fasciculata cells showing rounded mitochondria $(\mathrm{M})$ with vesicular cristae. The cytoplasm contains profiles of smooth endoplasmic reticulum (S) and a small Golgi complex (G). Li; lipid droplet. ax2500,bx8000 

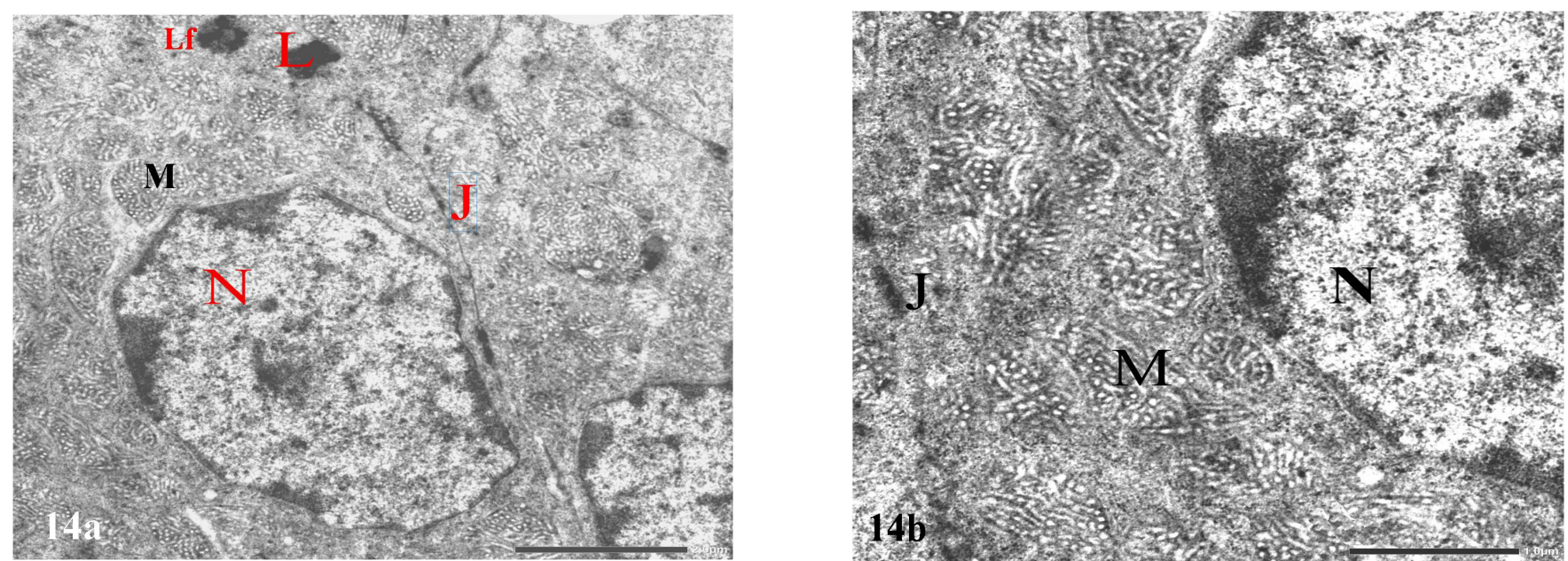

Fig.14a,b: Electron micrographs of ZR cells of the same group. Their cytoplasm shows numerous closely packed mitochondria (M), with tubulo-vesicular cristae. Lf; lipofuscin pigment in a, L; lysosome, J; desmosome junction, N; nucleus. ax4000,bx8000.
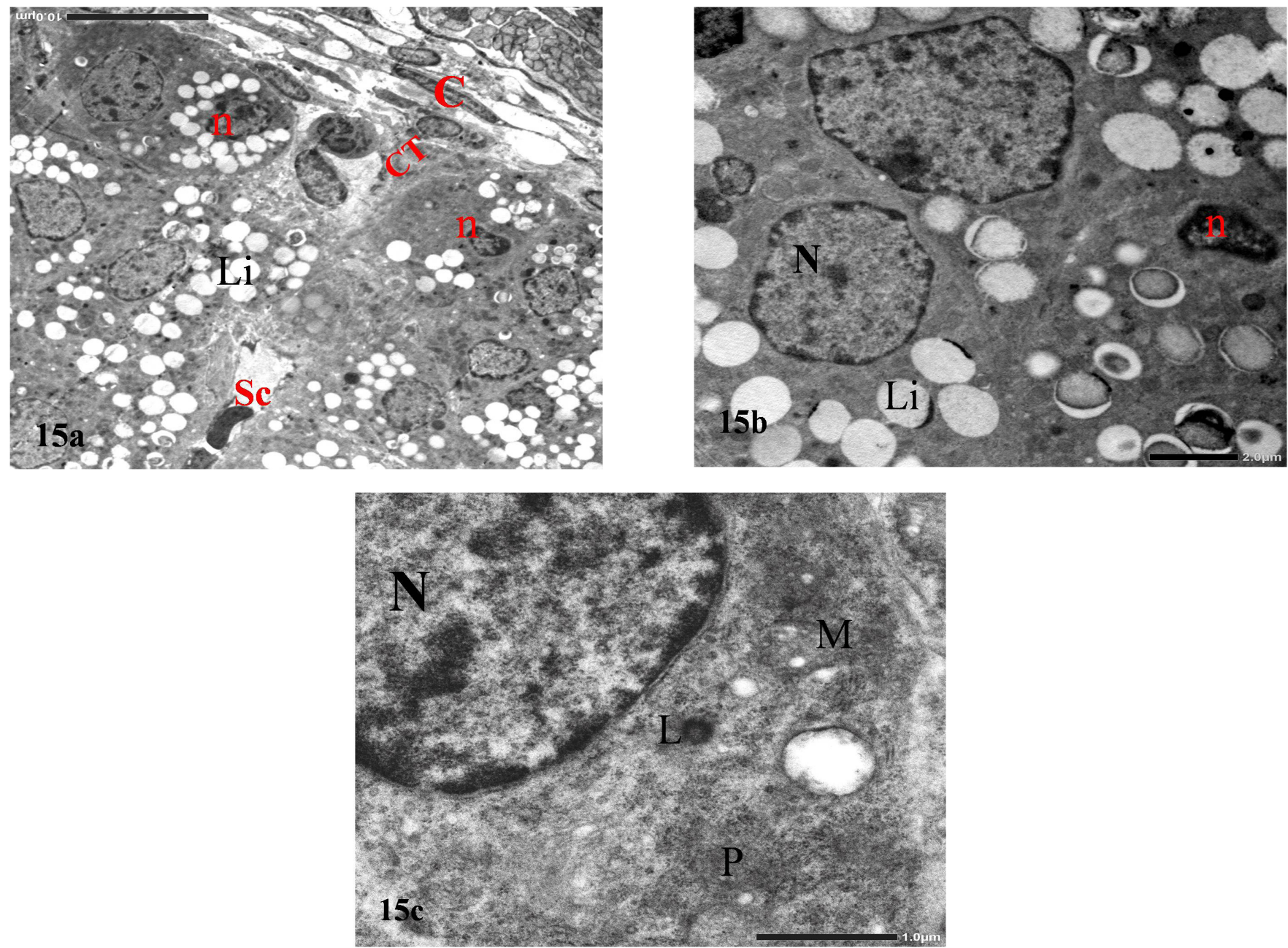

Fig. 15 a-c: Electron micrographs of zona glomerulosa of group II. a) Showing group of ZG cells under the capsule (C). Some cells exhibit small relatively dense nuclei (n). Sc; sinusoidal capillary, CT; connective tissue trabeculae, Li; lipid droplets. b) ZG cells with euchromatic nuclei $(\mathrm{N})$, their cytoplasm shows some lipid droplets (Li). One cell exhibits a small heterochromatic nucleus (n). C) A part of the ZG cell showing mitochondria with disrupted cristae (M). L; lysosome, N; nucleus, P; polysomes. ax800,bx2500, cx8000. 

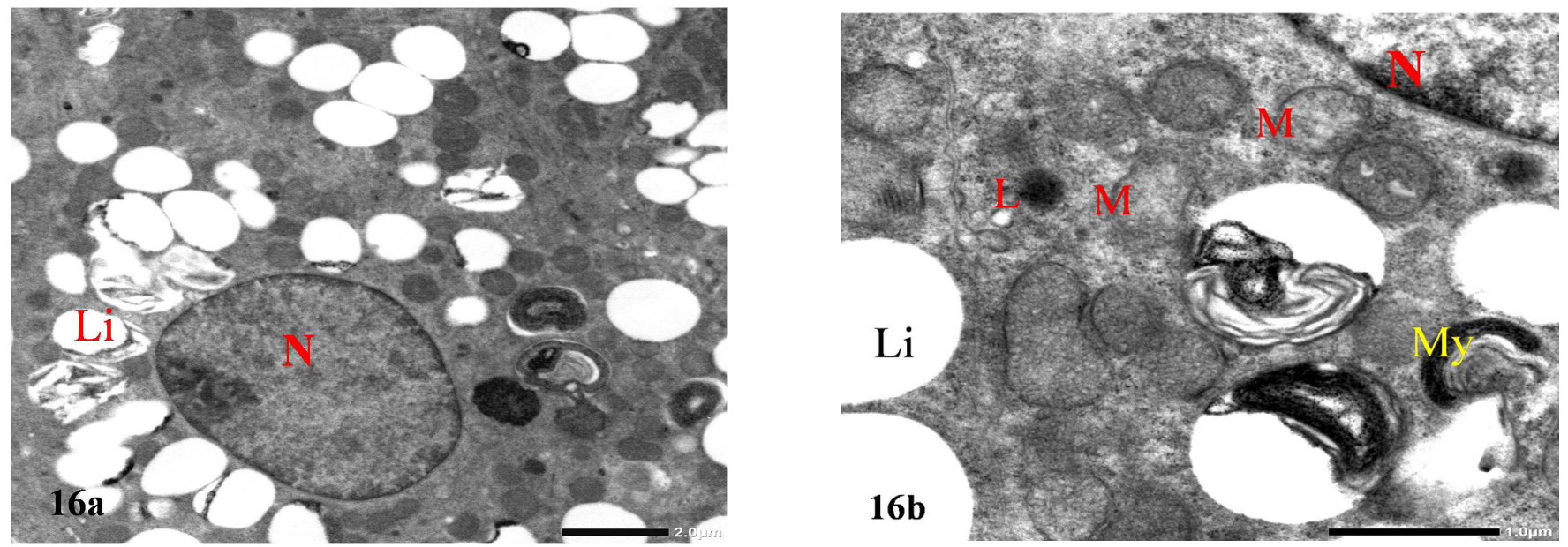

Fig. 16a,b: Electron micrographs of ZF cells of the same group. a) The cytoplasm is loaded with many lipid droplets (Li). N; nucleus. b) Mitochondria (M) appear with ill-defined cristae. Multiple myelin figures (My) are also seen. L; lysosome, N; nucleus, Li; lipid droplet. ax2000,bx8000
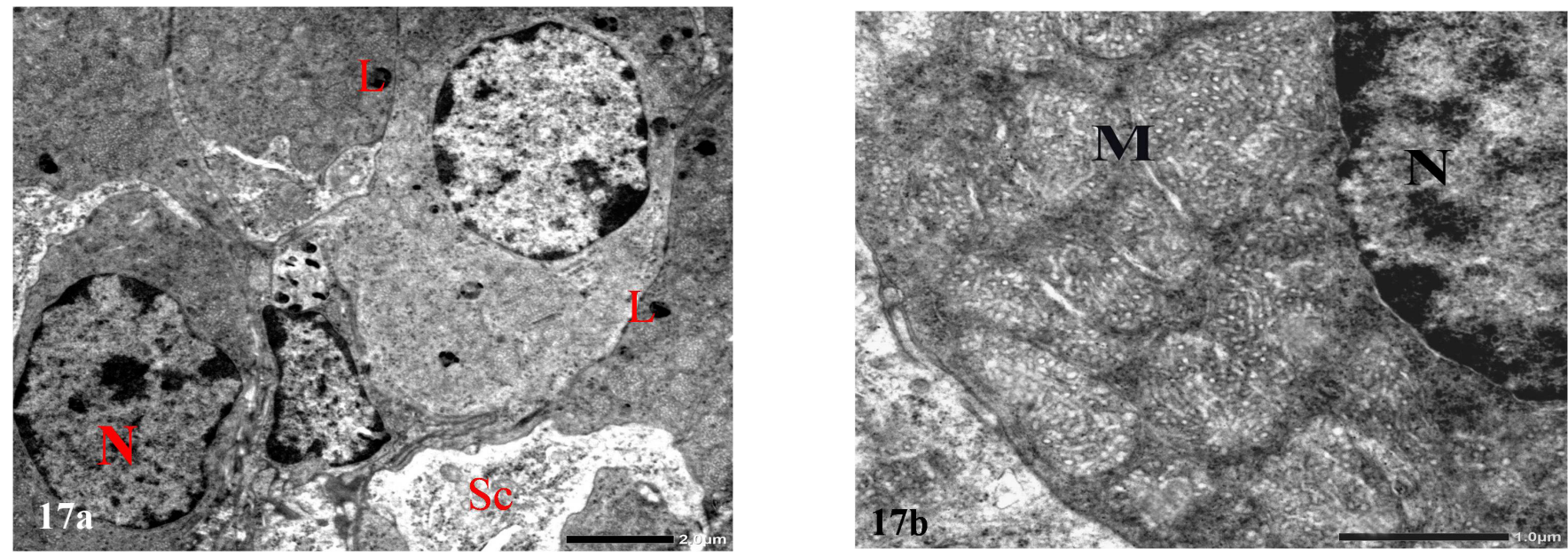

Fig. 17a,b: Electron micrographs of adrenal cortex of the same group displaying part of the ZR. a) One cell exhibit a slightly irregular nucleus (N). Multiple lysosomes are also seen (L). Sc; sinusoidal capillary. b) Part of ZR cells showing closely packed mitochondria (M) with tubulovesicular cristea. N; nucleus. ax2500,bx8000.
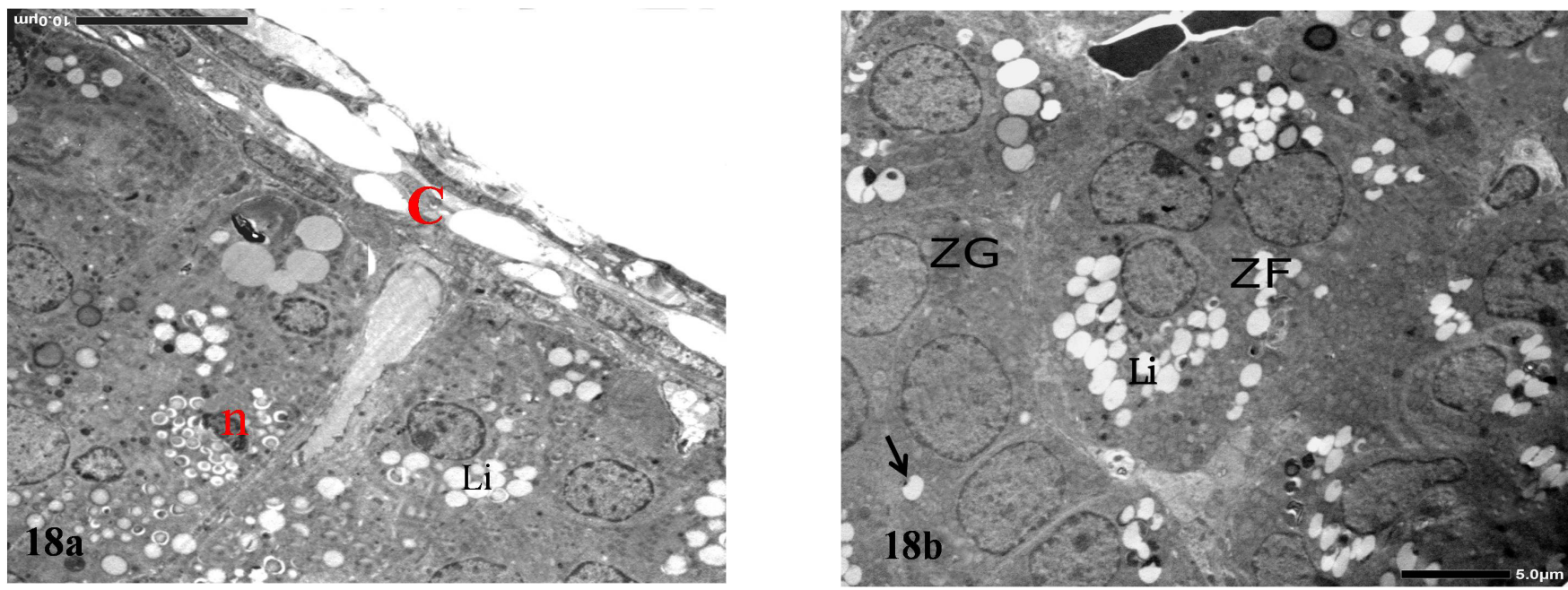

Fig.18 a,b: Electron micrographs of group III showing; cells of ZG with relatively few cytoplasmic lipid droplets (Li) and dense cytoplasm. Some nuclei (n) are small and heterochromatic. C; capsule. b) Part of the adrenal cortex showing zona glomerulosa cells with few cytoplasmic lipid droplets (arrow).The adjacent zona fasciculate shows cells with many lipid droplets (Li). ax800,bx 1000. 

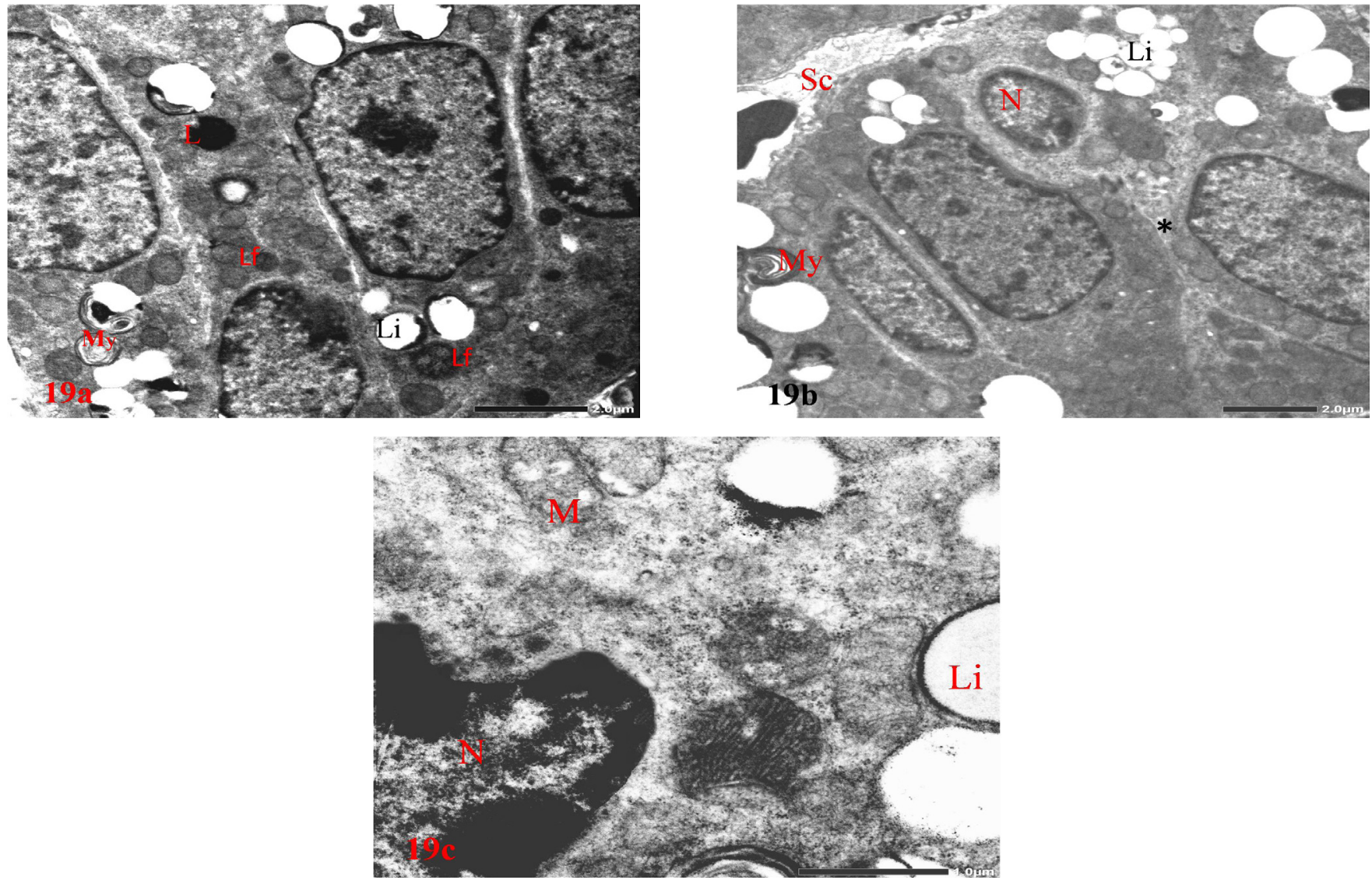

Fig. 19 a-c: Electron micrographs of ZG cells of group III showing; a) Cells with relatively few cytoplasmic lipid droplets (Li). L; lysosome, My; myelin figure, Lf; lipofucsin pigments. b) Adjacent ZG cells, one reveal an euchromatic nucleus $(\mathrm{N})$ and cellular extensions $(*)$ near a sinusoidal capillary (Sc). My; myelin figure, Li; lipid droplets. c) Part of an irregular dense nucleus (N) with condensed peripheral heterochromatin. Some mitochondria (M) show disrupted cristae. Li; lipid droplet. ax3000,bx2500,cx8000.
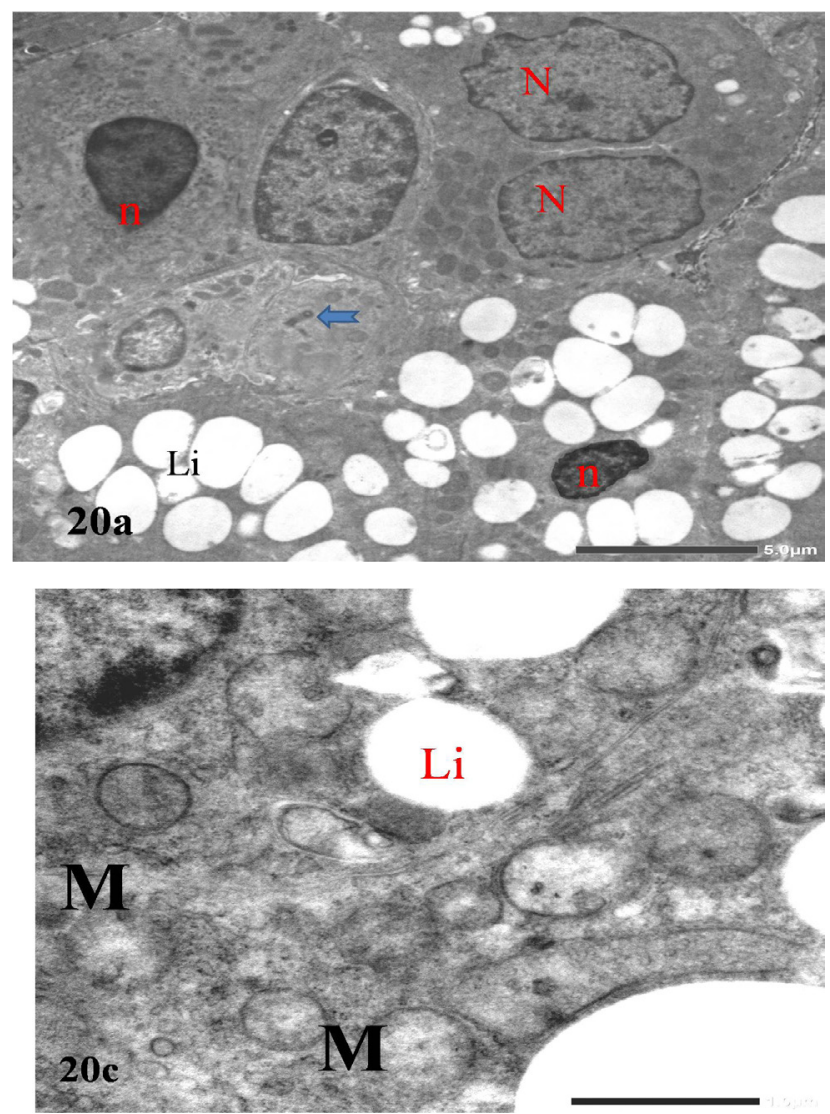

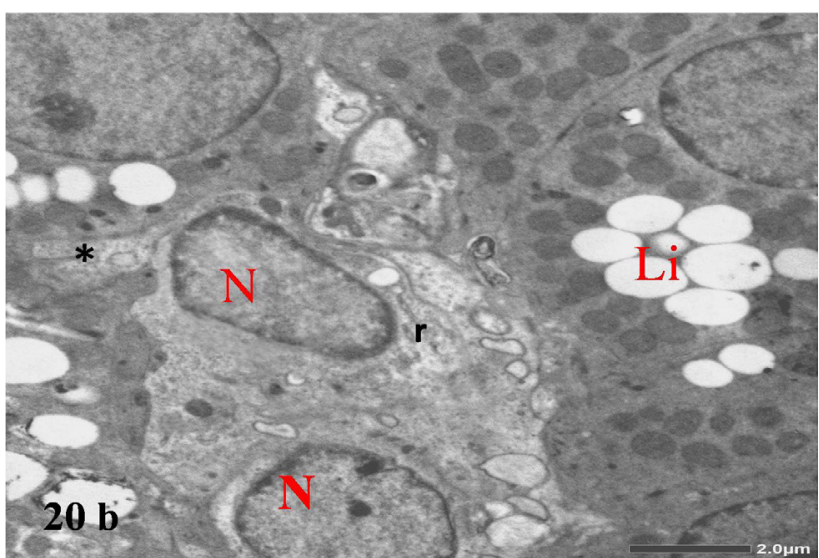

Fig. 20 a-c: Electron micrographs of ZF of the same group. a) Some cells show many lipid droplets (Li), others show relatively dense cytoplasm with sparse lipid droplets and euchromatic nuclei $(\mathrm{N})$. Two cells show dense nuclei (n). One cells reveals a centeriol (arrow).

b) ZF cells showing cytoplasmic lipid droplets (Li). Two intervening cells with euchromatic nuclei $(\mathrm{N})$, cytoplasmic pseudopodia $(*)$ and a profile of rough endoplasmic reticulum (r) are also seen.

c) A profile of the ZF showing mitochondria (M) with ill-defined cristae. Li; lipid droplet. ax1500,bx2500, c x8000 

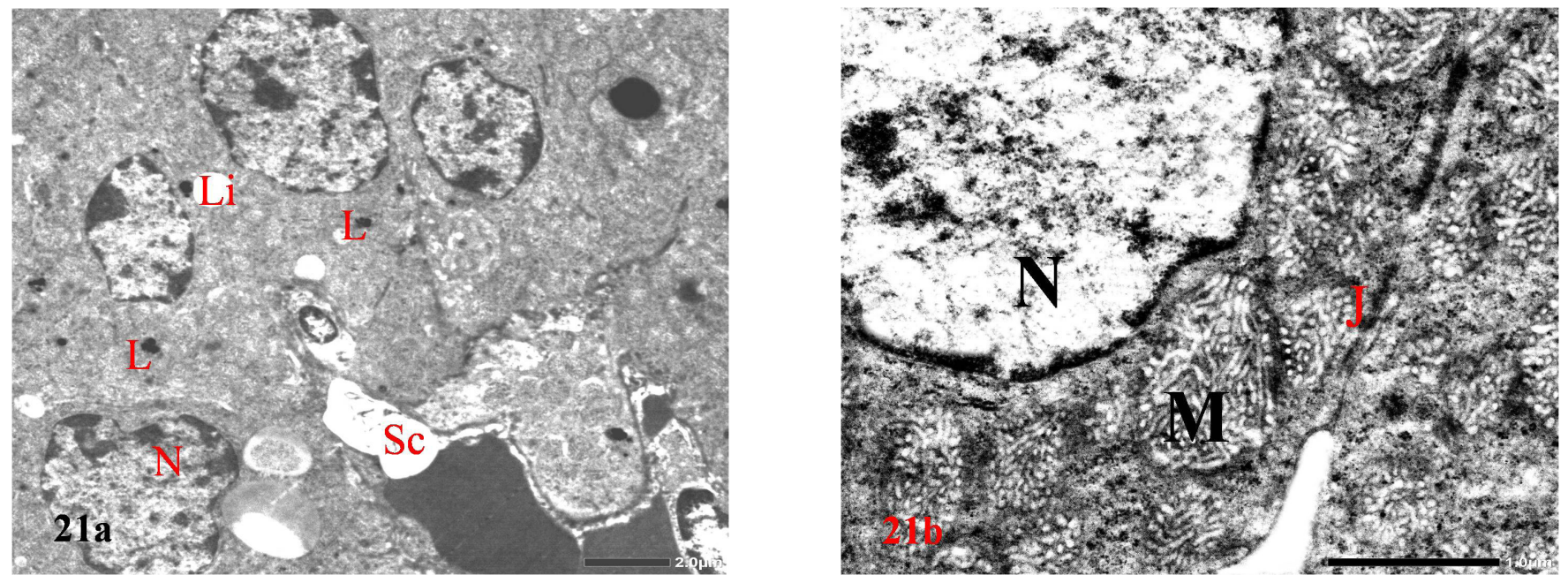

Fig21a,b: Electron micrographs the ZR of group III illustrating; a) Group of cells with an adjacent large sinusoidal capillary (Sc). One cell shows an irregular nucleus $(\mathrm{N})$. The cytoplasm reveals scanty lipid droplet (Li) and lysosomes (L). b) Part of two adjacent cells of the ZR of the same group with desmosome junction (J). The cytoplasm demonstrates numerous mitochondria with tubulo-vesicular cristae (M). ax2000,bx8000.

\section{DISCUSSION}

Tributyltin (TBT), have been widely used in a wide variety of consumer products and has been identified as an endocrine disruptor. TBT might alter mechanisms of action of hormones in endocrinal organs via mimicking or blocking hormonal action ${ }^{[10]}$. Thus the present study was carried out to investigate the probable toxic effect of TBT on adrenal cortical cells of adult male albino rats.

All steroid hormones are derived from cholesterol. A number of steps catalyzed by enzymatic reactions occur in the mitochondria and endoplasmic reticulum of all steroidogenic cells converting cholesterol into steroid hormones through the sequential actions of a series of cytochrome P450 (CYP) enzymes and hydroxysteroid dehydrogenases (HSDs) ${ }^{[20]}$.

Aldosterone and corticosterone share the first steps of their biosynthetic pathways. Zone-specific expression of steroidogenic enzymes results in the biosynthesis of aldosterone (via aldosterone synthase) in the zona glomerulosa(ZG), and corticosterone (via 11 $\beta$-hydroxylase) in the zona fasciculata (ZF). ${ }^{[1]}$ The zona reticularis (ZR) does not secrete androgens in rats ${ }^{[22]}$.

An immunohistochemical study led to the discovery of an undifferentiated cell zone (ZU) between $\mathrm{ZG}$ and $\mathrm{ZF}$ in the rat adrenal gland ${ }^{[23]}$. In male this zone regresses by the increase of testosterone at puberty. In females, the zone persists for several weeks after puberty and then regresses by the first pregnancy ${ }^{[24]}$. That's why adult male rats were chosen in the present study to clarify the histological changes under the effect of TBT.

In the current study, after one week of exposure to TBT the histological examination of the adrenal cortex revealed alteration in cells of the ZG as well as those of ZF. No previous reports have shown alteration in the cells of ZR after TBT exposure which was in line with the current study that showed no evident histological alteration as compared to the control group.

The current study showed aggregates of exclusively hypertrophic cells readily identified in the ZG and ZF. The morphological features of the hypertrophic cells appeared with vacuolated cytoplasm. This result might be a consequence of accumulations of cholesterol / intermediate steroids inside the cells. It was reported that the functional significance of this diffuse cellular hypertrophy might result from increased storage or failure to release steroid precursors. Similar findings were reported and involved cholesterol storage and /or the mechanisms of cholesterol import into mitochondria ${ }^{[25]}$.

The present study showed several cells with irregular nuclei and condensed chromatin that might be related to degeneration. Their cytoplasm was loaded with lipid droplets. In addition, many lysosomes and myelin figures were other findings which reflected increased digestion of the accumulated intracellular lipids. The mitochondria also showed ill-defined cristae. These findings were in accordance with Abd El-Gawad FA et al., ${ }^{[26]}$ who found irregular nuclei with condensed chromatin and abundant lipid droplets together with multiple lysosomes within cells of ZG and those of ZF after exposure to stress.

In the present study, the adrenal cells of $\mathrm{ZG}$ and $\mathrm{ZF}$ of the rats of group III exhibited loss of normal cellular arrangement and the presence of dark nuclei with hypertrophic cells alternating with cells with highly acidophilic cytoplasm and pyknotic nuclei. Similar observations were reported by some researchers who stated that the stressed adrenal glands were characterized by the presence of plump of cells with greatly increased eosinophilia of the cytoplasm ${ }^{[26]}$.

In the current study, in group III (received TBT for two weeks), the TBT resulted in a decrease in cortical vacuolation versus concurrent control group which 
might have occurred as a consequence of the shutdown of steroidogenesis due to degenerative cellular changes. Ultrastructuraly, the cells showed electron-dense cytoplasm and the mitochondria showed disrupted cristae. These changes have been considered as signs of lowered functional activity of steroid-producing adrenal cells ${ }^{[27]}$ and correlate well with adrenocortical overstimulation and /or degeneration ${ }^{[28,29]}$. Many circulatory disorders were expected as a result of compression of the hypertrophied cells on the sinusoidal capillaries. This might cause hypoxia which is proved to inhibit adrenal functional activity ${ }^{[30]}$.

Organotins (OTs) have been previously reported to alter various enzymes involved in steroid hormone biosynthesis which vary not only with tissue or exposed cells but also with the dose and time of exposure resulting in impaired steroidogenesis and adrenal insufficiency ${ }^{[31,32]}$. Studies have described a relationship between endocrine dysfunction induced by OTs and their effects on the enzyme CYP. They were originally believed to be potent CYP enzyme inhibitors ${ }^{[33,34]}$. Therefore, it is not surprising that adrenal steroidogenesis of aldosterone and corticosterone, which are catalyzed almost entirely by CYP enzymes are consequently also affected. This might cause a diffuse increase in cytoplasmic accumulation of cholesterol and intermediate steroids indicating a decreased transformation of cholesterol to steroids. Several studies displayed that exposure to TBT increased intracellular lipid storage ${ }^{[35,36]}$ even if the exposure was in non-cytotoxic doses ${ }^{[37]}$.

In addition, many researchers reported lipid and cholesterol accumulation in the cells of the adrenal gland associated with decreased cholesterol utilization and increased cholesterol level in the adrenal cells ${ }^{[38]}$ associated with increased serum cholesterol levels afterTBT intake ${ }^{[39]}$.

Transport of cholesterol into the mitochondria is aided by the steroidogenic acute regulatory protein (StAR). Since StAR protein and steroidogenic CYP are a common system in steroidogenic organs, the disturbance of the steroidogenic system is presumably not limited to one of them only. However, it is possible that TBT affects adrenocortical function as a result of abnormal StAR function due to its direct inhibitory effect on the expression of StAR ${ }^{[40]}$. Physiologically, acute regulation, over minutes, occurs through the phosphorylation of preexisting StAR which is then followed by synthesis of new StAR protein ${ }^{[38]}$. This might explain the non -significant decrease in hormonal levels after one week of exposure

One of the explanations regarding the toxic effect of TBT was its effect on the expression of transforming growth factor $\beta 1$ (TGF- $\beta 1$ ). TGF- $\beta 1$ is a major regulator of steroidogenic cells and StAR expression ${ }^{[41]}$.TGF- $\beta 1$ has been shown to exert strong inhibitory effects on adrenocortical cell steroidogenesis. TGF- $\beta 1$ decreases the level of StAR mRNA in a concentration- and timedependent manner. Generally, high levels of TGF $\beta 1$ lead to reduced plasma aldosterone and corticosterone levels. The data reported that TGF- $\beta 1$ transcripts were increased after TBT administration ${ }^{[42,43]}$.
It is worth noting that in addition to interaction with steroidogenesis, TBT is mainly metabolized in the liver and the metabolites of TBT might be responsible for some of its toxicity. Such metabolites disrupt glucocorticoid receptor (GR)-mediated regulation of gene transcription at the initial step of receptor activation by blocking ligand binding to the receptor supporting the evidence that they directly inhibit GR activity ${ }^{[44]}$.

Nevertheless, together with the previously mentioned studies, the endocrine dysfunction due to TBT exposure might be mediated also by increased oxidative stress and damages to mitochondrial function ${ }^{[45]}$. In this regard, the inhibition of ATP synthesis could thereby trigger endocrine dysfunctions ${ }^{[46]}$. Moreover, the mitochondria were the main organelle being affected in the $\mathrm{ZG}$ and the ZF in the current study. Mitochondria were shown to be highly sensitive to treatment with organotins. TBT, induces mitochondrial swelling, inhibits the ATP synthesis and alter ion transport across membranes ${ }^{[5]}$. This was in line with the current study which showed mitochondrial changes in group II and III. Combining previous results, it has been suggested that oxidative damage is one of the most important critical toxic mechanisms of $\mathrm{TBT}^{[47-49]}$. Oxidative stress (OS) generation is a result of increased production of reactive oxygen species (ROS). In various organs, including the adrenal gland, lipid peroxidation was increased and played an important role in the pathogenesis of adrenal insufficiency ${ }^{[50-52]}$

ROS have been indicated to play a key role in TBT-induced toxic responses in vitro and in vivo ${ }^{[53,54]}$. Excessive amounts of ROS if not balanced might lead to cell dysfunction/ damage/ death and impede steroidogenesis ${ }^{[55-57]}$. Moreover, there is evidence that StAR and CYP activity are sensitive to both physiological and pathophysiological levels of ROS with a net result of a reduction in their protein expression of $\mathrm{StAR}^{[58,59]}$. In addition, a significant correlation has been observed between the antioxidant parameters and TBT exposure ${ }^{[13,59]}$.

In order to protect the cells from the toxic effects of ROS, adrenocortical cells contain high concentrations of biological antioxidants. The antioxidant defense systems have been shown to become significantly decreased after TBT exposure with an increase in lipid peroxidation ${ }^{[60]}$.

In a study, the antioxidant defense system has been shown to increase in the initial phases of TBT toxicity. Such increase was explained on the basis that during the first week, the cellular protective machinery is activated ${ }^{[60]}$. This might explain the mild histological changes and nonsignificant alteration in the hormonal levels of group II.

Another possible mechanism claimed to be the cause of TBT toxicity was apoptosis. A wealth of studies demonstrated that TBT induced ROS generation and marked loss in cell viability was attributed to apoptosis ${ }^{[39,59,60]}$. This apoptotic effect of TBT was documented in various organs. It might lead to more progressive alterations and finally irreversible dysfunction and anti-steroidogenic activity ${ }^{[61]}$. 
A study showed that the toxicity of TBT was less evident in a shorter time of exposure, but the toxicity was increased on longer durations signifying that the effect is time-dependent ${ }^{[62]}$. This was in line with the current study. This might explain the more degenerative changes after the $2^{\text {nd }}$ week. Among other abnormalities, several studies showed that TBT induced severe cellular damage that was even replaced by fibrous tissue ${ }^{[49]}$ in a time-dependent manner via the direct toxic effects of $\mathrm{TBT}^{[39,61]}$

In the current study, immunoreaction and statistical analysis of the number of CD $44+$ ve cells were increased from week one to week two. CD44 comprises a family of cell adhesion and signaling molecules characteristic for mesenchymal stem cells. CD 44+ve cells were detected at the capsule in group II and were more significantly increased in group III. It could be commented that sources of stem cells from the bone marrow which might have reached the damaged areas via the circulation. Moreover, studies have provided evidence for the existence of adrenocortical cells with stem-like properties in mammalian species ${ }^{[63,64]}$ with their ability of migration by membrane extensions ${ }^{[65,66]}$. A study declared that cortical stem cells, first of all, appear between cortical cells in ZG and ZF approximately on the $7^{\text {th }}$ day of exogenous hyperthermia. On the $14^{\text {th }}$ day they proliferate in the deep portion of $\mathrm{ZF}^{[67]}$. It is now clear that distinct pools of stem/progenitor cells appear to be activated only in response to extreme demand ${ }^{[20,23,68]}$.

Data indicated that the adrenocortical stem cells in response to ACTH have the capacity to induce proliferation and differentiation into adrenal cortex like cells ${ }^{[69]}$. Progenitors have the potential to migrate and differentiate into steroid-producing cells, an ability greatly enhanced with high $\mathrm{ACTH}{ }^{[70,71]}$. Unfortunately, the proliferative effect of ACTH is time-dependant and that mitosis is inhibited in the longer term with failure of regeneration ${ }^{[72]}$.

Additionally, tin in tissues and blood after TBT administration was measured in several studies that showed its accumulation in various tissues including the adrenal cells ${ }^{[73]}$. Similarly, the tin level in the present study was significantly increased during the two weeks of the experimental TBT exposure.

Adrenal insufficiency is a life-threatening disorder that requires a complex and permanent hormone replacement. The current study declared that TBT is a threat to health and induced marked histological alterations in the glomerulosa and fasciculata cells which were time-dependent. This was associated with hormonal alteration and elevated serum tin levels. Therefore, TBT could be considered as an important environmental risk for structural and functional alterations in adrenal cortical cells. In addition, this study recommended isolation of stem and progenitor cells from adrenal cortex which could be cultured in vitro and trials to differentiate them into mineralocorticoid-and glucocorticoid-producing cells, therefore, providing a source of cells for replacement therapy to treat adrenal insufficiency.

\section{CONFLICTS OF INTEREST}

There are no conflicts of interest

\section{REFERENCES}

1. Diamanti-Kandarakis E, Bourguignon JP, Giudice LC, Hauser R, Prins GS, Soto AM, Zoeller RT, Gore AC. Endocrine-disrupting chemicals: an Endocrine Society scientific statement. Endocr Rev 2009;30 (4):293-342.

2. Damstra T, Barlow S, Bergman A, Kavlock R, Van Der Kraak G. Global assessment of the stateof-the-science of endocrine disruptors. Geneva: TheInternationalProgramme on Chemical Safety (IPCS), World HealthOrganization. 2002.

3. Antizar-Ladislao B1. Environmental levels, toxicity and human exposure to tributyltin (TBT)contaminated marine environment. Environ Int. 2008; 34(2): 292-308.

4. Anne Kirstine Müller Elsa Nielsen Ole Ladefoged .Tributyltin compounds (TBT). Evaluation of health hazards and proposal of health based quality criteria for soil and drinking water. The Danish Environmental Protection Agency 2013; 1-56.

5. deCarvalho Oliveira R, Santelli RE. Occurrence and chemical speciation analysis of organotin compounds in the environment: a review. Talanta2010; 82(1):9-24.

6. Chen Q, Zhang Z, Zhang R, Niu Y, Bian X, Zhang Q. Tributyltinchloride-induced immunotoxicity and thymocyte apoptosis are related to abnormal Fas expression. Int J Hyg Environ Health 2011; 214: $145-150$.

7. Grote K, Stahlschmidt B, Talsness CE, Gericke C, Appel KE, ChahoudI. Effects of organotin compounds on pubertal male rats. Toxicology 2004;202:145-158.

8. Bertuloso BD, Podratz PL, Merlo E, et al. Tributyltin chloride leads to adiposity and impairs metabolic functions in the rat liver and pancreas. ToxicolLett. 2015;235:45-59.

9. Incollingo Rodriguez AC, Epel ES, White ML, Standen EC, Seck JR, Tomiyama AJ. Hypothalamic-pituitary-adrenal axis dysregulation and cortisol activity in obesity: a systematic review. Psychoneuroendocrinology 2015;62:301-318.

10. Tabb MM, Blumberg B. New modes of action for endocrine-disrupting chemicals. MolEndocrinol 2006;20(3):475-82.

11. Pihlajoki M, Dorner J, Cochran RS, Heikinheimo M, Wilson DB. Adrenocortical zonation, renewal, and remodeling. Front Endocrinol (Lausanne). 2015;6:27.

12. Ishihara Y,Kawami $\mathrm{T}$, Ishida $\mathrm{A}$, Yamazaki $\mathrm{T}$. Tributyltin induces oxidative stress and neuronal injury by inhibiting glutathione S-transferase in rat organotypic hippocampal slice cultures. Neurochem In. 2012; 60(8):782-790. 
13. Mitra S, Gera R, Singh V, Khandelwal S Comparative toxicity of low dose tributyltin chloride on serum, liver, lung and kidney following subchronicexposure. Food ChemToxicol 2014;64:335-443

14. Zhao M, Li X, Li M, GaoY. Effects of anesthetics pentobarbital sodium and chloral hydrate on urine proteome. PeerJ. 2015; 3: e813-27.

15. Vahl TP, Ulrich-Lai YM, Ostrander MM, Dolgas $\mathrm{CM}$, Elfers EE, Seeley RJ, et al. Comparative analysis of ACTH and corticosterone sampling methods in rats. Am J PhysiolEndocrinolMetab 2005; 289(5): E823-828.

16. Palmer CD, Lewis ME, Geraghtya CM, Barbosa FJ, Parsonsa PJ. Determination of lead, cadmium and mercury in blood for assessment of environmental exposure: a comparison between inductively coupled plasma-mass spectrometry and atomic absorption spectrometry. SpectrochimActa B Atom Spectrosc 2006; 61 (8): 980-990.

17. Bancroft JD, Layton C. The hematoxylin and eosin, connective and mesenchymal tissues with their stains. In: Suvarna SK, Layton C and Bancroft JD, editors. Bancroft's Theory and Practice of Histological Techniques. 7th edition, ch 10 and 11, Churchill Livingstone, Philadelphia, 2013; 173 - 212.

18. Siiskonen H, Törrönen K, Kumlin T, Rilla K, Tammi MI, Tammi RH Chronic UVR causes increased immunostaining of CD44 and accumulation of hyaluronanin mouse epidermis. JHistochemCytochem. 2011;59(10):908-917.

19. Woods AE, Stirling JW. Transmission electron microscopy applications. In: Suvarna SK, Layton C, Bancroft JD, editors. Theory and Practical Histological Techniques. 7th edition, ch 22, Churchill Livingstone, Philadelphia 2013; 493 - 538.

20. Fumiko M. Functional zonation of the rat adrenal cortex: the development and maintenance. ProcJpnAcadSer B 2014;90(5): 163-183.

21. Chandra S, Hoenerhoff M, Peterson R. Endocrine glands. In Toxicologic pathology. Nonclinical safety assessment (P. Sahota, J. Popp, J. Hardisty and C. Gopinath, eds.), CRC Press, Boca Raton 2013; 680-692.

22. Inomata A, Sasano H. Practical approaches for evaluating adrenal toxicity in nonclinical safety assessment .J ToxicolPathol 2015 ;28(3):125-32.

23. Mitani, F., Mukai, K., Miyamoto, H., Suematsu, M. and Ishimura, Y. The undifferentiated cell zone is a stem cell zone in adult rat adrenal cortex. Biochim. Biophys.Acta 2003; 1619:317-324.

24. Tsujio M, Mizorogi T, Nishijima K, Kuwahara S, Aoyama H, Ohno T, et al. A morphometric study of the adrenal cortex of the female DDD mouse.J Vet Med Sci 2009 ;71(2):183-187.
25. Harvey PW, Sutcliffe C. Adrenocortical hypertrophy: Establishing cause and toxicological significance. J ApplToxicol 2010;30: 617-26.

26. Abd El-Gawad FA, Zaki SM, El-Shaarawy EA, Radwan RA, Aboul-Hoda BE. Histological and histomorphometric reorganization of the adrenal cortex of adolescent male albino rat following exposure to stress. Med J Cairo Univ 2016; 84 (1): 1107 - 1112.

27. Tsomartova DA, Yaglova NV, Obernikhin SS, Nazimova SV, Yaglov VV. Secretion of adrenal zonaglomerulosa cells in rats exposed to low doses of Dichlorodiphenyltrichlorethane during prenatal and postnatal development. RusOMJ 2018; 7(3):e0302.

28. Cigánková V, Zibrín M, Holovská K. Effect of long - term experimental hypodynamy on the adrenal glands of japanese quails: an ultrastructural study. Bull Vet InstPulawy 2005; 49: 449 - 453.

29. Bozzo A, Sonez C, Cobeta I, Avila R, Rolando A, Romanini $\mathrm{M}$, et al. Chronic stress effects on adrenal cortex cellular proliferation in pregrnant rats. Int $\mathrm{J}$ Morphol 2011; 29: 1148-1157.

30. Orente $M$, Mirapeux R, Miguel M, Longmei W, Volk D, Cervos-Navarro J. Chronic hypoxia induced ultrastructural changes in the rat adrenal zonaglomerulosa. HistolHistopathol 2002; 17: $185-190$.

31. Marques VB, Faria RA, Dos Santos L. Overview of the pathophysiological implications of organotins on the endocrine system.Front Endocrinol (Lausanne)2018;9:101.

32. Martinez-Arguelles DB, Papadopoulos V. Mechanisms mediating environmental chemical-induced endocrine disruption in the adrenal gland.Front Endocrinol(Lausanne) 2015; 6: 29.

33. Lang PP, Delgado Filho VS, Lopes PF, Cavati SG, Matsumoto ST, Samoto VY, et al. Tributyltin impairs the reproductive cycle in female rats. J Toxicol Environ Health A 2012;75:1035-1046.

34. Sena GC, Freitas-Lima LC, Merlo E, Podratz PL, de Araujo JF, Brandao PA, et al. Environmental obesogentributyltin chloride leads to abnormal hypothalamic-pituitary-gonadal axis function by disruption in kisspeptin/leptin signaling in female rats. ToxicolApplPharmacol 2017; 319:22-38.

35. Zuo Z, Chen S, Wu T, Zhang J, Su Y, Chen Y, et al. Tributyltin causes obesity and hepatic steatosis in male mice. Environ Toxicol. 2011;26(1):79-85.

36. 36- Yan H, Guo H, Cheng D, Kou R, Zhang C, Si J. Tributyltin reduces the levels of serum adiponectin and activity of AKT and induces metabolic syndrome in male mice. 2018;33(7): 752-758. 
37. Chen YW, Lan KC, Tsai JR, Weng TI, Yang CY, Liu SH.Tributyltinexposure at noncytotoxic doses dysregulates pancreatic $\beta$-cell function in vitro and in vivo. Arch Toxicol2017; 91(9):3135-3144.

38. Kraemer FB. Adrenal cholesterol utilization. Mol Cell Endocrinol 2007;265-266:42-45.

39. Merlo E, Podratz PL, Sena GC, de Araújo JF, Lima LC, Alves IS, et al. The environmental pollutant tributyltin chloride disrupts the hypothalamic pituitary-adrenal axis at different levels in female rats. Endocrinology 2016; 157(8): 2978-2995.

40. Clark BJ, Hudson EA. Star protein stability in $\mathrm{y} 1$ and kin-8 mouse adrenocortical cells. Biology (Basel) 2015; 4(4): 200-215.

41. Kakoki M, Pochynyuk OM, Hathaway CM, et al. Primary aldosteronism and impaired natriuresis in mice underexpressing TGFbeta1. ProcNatlAcadSci U S A. 2013;110(14):5600-5605.

42. Matsuki K, Hathaway CK, Lawrence MG, Smithies O, Kakoki M1. The role of transforming growth factor $\beta 1$ in the regulation of blood pressure.CurrHypertens Rev. 2014;10(4):223-38.

43. Pavlikova N, Arukwe A. Immune-regulatory transcriptional responses in multiple organs of Atlantic salmon after tributyltin exposure, alone or in combination with forskolin.J Toxicol Environ Health A 2011;74(7-9):478-493.

44. Gumy C, Chandsawangbhuwana C, Dzyakanchuk AA, Kratschmar DV, Baker ME, Odermatt A. Dibutyltin disrupts glucocorticoid receptor function and impairs glucocorticoid-induced suppression of cytokine production. PLoS ONE 2008; 3(10): e3545.

45. Yamada S, Kotake Y, Nakano M, Sekino Y, Kanda Y. Tributyltin induces mitochondrial fission through NAD-IDH dependent mitofusin degradation in human embryonic carcinoma cells. Metallomics 2015; $7: 1240-1246$.

46. Von BC, Brunner J, Dimroth P. The ion channel of F-ATP synthase is the target of toxic organotin compounds. ProcNatlAcadSci U S A 2004; 101:11239-11244.

47. Hinson JP, Raven PW.Effects of endocrine-disrupting chemicals on adrenal function. Best Pract Res ClinEndocrinolMetab 2006; 20(1):111-120.

48. Zhi-HuaLi, Ping Li,, Ze-Chao Shi.Chronic exposure to tributyltin induces brain functional damage in juvenile common carp (Cyprinuscarpio) PLoS ONE 2015; 10(4): e0123091.

49. Zhou J, Zhu XS, Cai ZH. Tributyltin toxicity in abalone (Haliotisdiversicolorsupertexta) assessed by antioxidant enzyme activity, metabolic response, and histopathology. J Hazard Mater 2010; 183: 428-433.
50. Chakraborty A, Mondal C, Sinha S, Mandal J, Chandra AK. Amiodarone induced oxidative stress in stress - vulnerable organs of adult male rats. Asian J Clin Pharm Res 2014; 7(4): 177-183.

51. Malikova J, Fluck CE.Novel insight into etiology, diagnosis and management of primary adrenal insufficiency.Horm Res Paediatr 2014; 82: 145-157.

52. Prasad R, Kowalczyk JC, Meimaridou E, Storr HL, Metherell LA. Oxidative stress and adrenocortical insufficiency. J Endocrinol 2014; 221: R63-73.

53. Mitra S1, Gera R, Siddiqui WA, Khandelwal S. Tributyltin induces oxidative damage, inflammation and apoptosis via disturbance in blood-brain barrier and metal homeostasis in cerebral cortex of rat brain: an in vivo and in vitro study. Toxicol 2013; 310:39-52.

54. Zhang Y, Chen Y, Sun L, Liang J, Guo Z, Xu L. Protein phosphatases $2 \mathrm{a}$ as well as reactive oxygen species involved in tributyltin-induced apoptosis in mouse livers. Environ Toxicol 2014;29:234-242

55. Wang CN, Liu YJ, Duan GL, Zhao W, Li XH, et al. CBS and CSE are critical for maintenance of mitochondrial function and glucocorticoid production in adrenal cortex. Antioxid Redox Signal 2014; 21: 2192-2207.

56. Wang CN, Duan GL, Liu YJ, Yu Q, Tang XL, et al. Overproduction of nitric oxide by endothelial cells and macrophages contributes to mitochondrial oxidative stress in adrenocortical cells and adrenal insufficiency during endotoxemia. Free RadicBiol Med 2015; 83: $31-40$.

57. Huang BW, Tsuji Y. Reactive oxygen species (ROS) homeostasis and redox regulation in cellular signaling. Cellular Signalling2012;24:981-990.

58. Shi Z, Feng Y, Wang J, Zhang H, Ding L, Dai J. Perfluorododecanoic acid-induced steroidogenic inhibition is associated with steroidogenic acute regulatory protein and reactive oxygen species in cAMP-stimulated Leydig cells. ToxicolSci 2010; 114:285-294.

59. Korytowski W, Pilat A, Schmitt JC, Girotti AW. Deleterious cholesterol hydroperoxide trafficking in steroidogenic acute regulatory (StAR) protein-expressing MA-10 Leydig cells: implications for oxidative stress-impaired steroidogenesis. J BiolChem 2013; 288 (16):11509-11519.

60. Kanimozhi V, Palanivel K, Akbarsha MA, Kadalmani B. Tributyltin-mediated hepatic, renal and testicular tissue damage in male Syrian hamster (Mesocricetusauratus): a study on impact of oxidative stress.Springerplus 2016;5(1):1523.

61. Mitra S, Srivastava A, Khanna S, Khandelwal S. Consequences of tributyltin chloride induced stress in Leydig cells: an ex-vivo approach. Environ ToxicolPharmacol 2014; 37(2):850-60. 
62. Li ZH, Li P, Shi ZC. Chronic effects of tributyltin on multiple biomarkers responses in juvenile common carp, Cyprinuscarpio. Environ Toxicol 2016; 31(8):937-44.

63. Dörner J, Martinez Rodriguez V, Ziegler R, Röhrig T, Cochran RS, Götz RM, et al. GLI1+ progenitor cells in the adrenal capsule of the adult mouse give rise to heterotopic gonadal-like tissue. Mol Cell Endocrinol. 2017; 5(441):164-175.

64. Walczak EM, Hammer GD. Regulation of the adrenocortical stem cell niche: implications for disease. Nat Rev Endocrinol 2015;11(1):14-28.

65. Baharvand H1, Matthaei KI. The ultrastructure of mouse embryonic stem cells. Reprod Biomed Online. 2003;7(3):330-5.

66. Lauffenburger DA, Horwitz AF. Cell migration, a physically integrated molecular process. Cell 1996; (84):359-369.

67. Kashirina NK.The morphological and functional basis of the new conception about the suprarenal cortex regeneration.MEDICINA 2003; 39 (10):951-954

68. De Joussineau C, Sahut-Barnola I, Levy I, Saloustros E, Val P, Stratakis CA, et al. The cAMP pathway and the control of adrenocortical development and growth Mol Cell Endocrinol 2012; 351(1):28-36.

69. Pignatelli D, Ferreira J, Vendeira P, Magalhães MC, Vinson GP. Proliferation of capsular stem cells induced by ACTH in the rat adrenal cortex.Endocr Res 2002;28(4):683-91.

70. Balyura M, Gelfgat E, Steenblock C, Androutsellis-Theotokis A, Ruiz-Babot G, Guasti L, et al. Expression of progenitor markers is associated with the functionality of a bioartificial adrenal cortex. PLoS One 2018; 13(3):e0194643.

71. Steenblock C, Rubin de Celis MF, Delgadillo Silva LF, Pawolski V, Brennand A, Werdermann M, et al. Isolation and characterization of adrenocortical progenitors involved in the adaptation to stress. ProcNatlAcadSci U S A 2018; 115(51): 12997-13002.

72. Coutinho JV, Freitas-Lima LC, Freitas FF, Freitas FP, Podratz PL, Magnago RP, et al. Tributyltin chloride induces renal dysfunction by inflammation and oxidative stress in female rats. ToxicolLett 2016; 260:52-69.

73. Ren X, Wu X, Sui G, Gong Z, Yawson E, Wu B, et al. Chronic trimethyltin chloride exposure and the development of kidney stones in rats. J ApplToxicol 2015; 35:500-507. 


\section{الملخص العربى}

\section{دراسة هستولوجية لتاثير التريبوتيلتين على خلايا القشرة الكظرية لذكور الجرذان البيضاء البالغة}

أمانى عبد المنعم سليمان وسيلفيا كميل ساويويس

قسم علم الأنسجة وبيولوجيا الخلية ـ كلية الطب - جامعة الإسكندرية

المقدمة : تريبوتيلتين يستخدم على نطاق و اسع كطلاء مضادة للحشف فى السفن البحرية ـ انه يتسرب ببطء من الطلاء إلى الماء ويصبح مندمجا في التربة والحيو انات والنباتات. تم التعرف على مركب تريبوتبلتين كاحد مثبطات الغدد الصماء التى تتسبب في تلف مؤكسد. الهدف: تهدف هذه الدراسة إلى التحقيق في التأثثر السام المحتمل لتريبوتيلتين على خلايا القترة الكظرية لذكور الجرذان البيضاء البالغة لفترتين مختلفتين.

طرق البحث: أجريت هذه الدراسة على ع من ذكور الجرذان البيضاء البالغة و التي تم تقسيمها بالتساوي إلى سمجموعات. المجموعة الأولى: هي المجموعة الضابطة. المجموعة الثانية: تلقى كل جرذ تريبوتيلتين بجرعة ا مغ مرة و احدة يوميًا بو اسطة أنبوب معدة لمدة أسبوع و احد. المجمو عة الثالثة: تلقت نفس جر عة المجموعة الثانية لمدة أسبو عين متتاليين. تم إجر اء فحص هر مونات الالدوستيرون و الكورتيكوستيرون و ACTH و مستوى القصدير فى الدم . كما تم إعداد الغدة الكظرية للفحص المجهري الضوئى و الإلكترونى النافذ. بالإضافة إلى إجر اء در اسة هستوكيميائية لخلايا 44 CD الإيجابية. النتائج: أظهرت النتائج انخفاض كبير في مستوى الألدوستيرون و الكورتيكوستيرون مع زيادة في مستويات ACTH وزيادة في عدد خلايا CD44 الإيجابية في المجمو عة الثالثة بالمقارنة مع المجمو عات الأخرى. كثفت المجمو عة الثانية عن وجود فقدان فى البنية الطبيعية ، مع فجوات فى سيتوبلازم الخلايا فى الطبقة العقدية و الحزمية.وكذلك ظهرت ميتوكوندريا متحللة الاعر اف. وفي الوقت نفسه ، أظهرت المجموعة الثالثة قليل من قطر ات الدهون و أنوية داكنة في كلا المطبقتين. الخلاصة: تريبوتيلتين له آثار ضارة على خلايا الطبقة العقدية و الحزمية للغدة الكظرية و التي تعتمد على الوقت. 